NBER WORKING PAPER SERIES

\title{
DO PERCEPTIONS OF BALLOT SECRECY INFLUENCE TURNOUT? RESULTS FROM A FIELD EXPERIMENT
}

\author{
Alan S. Gerber \\ Gregory A. Huber \\ David Doherty \\ Conor M. Dowling \\ Seth J. Hill \\ Working Paper 17673 \\ http://www.nber.org/papers/w17673
}

\author{
NATIONAL BUREAU OF ECONOMIC RESEARCH \\ 1050 Massachusetts Avenue \\ Cambridge, MA 02138 \\ December 2011
}

This research was funded by Yale University's Center for the Study of American Politics and Institution for Social and Policy Studies. The views expressed herein are those of the authors and do not necessarily reflect the views of the National Bureau of Economic Research.

NBER working papers are circulated for discussion and comment purposes. They have not been peerreviewed or been subject to the review by the NBER Board of Directors that accompanies official NBER publications.

(C) 2011 by Alan S. Gerber, Gregory A. Huber, David Doherty, Conor M. Dowling, and Seth J. Hill. All rights reserved. Short sections of text, not to exceed two paragraphs, may be quoted without explicit permission provided that full credit, including $\odot$ notice, is given to the source. 
Do Perceptions of Ballot Secrecy Influence Turnout? Results from a Field Experiment Alan S. Gerber, Gregory A. Huber, David Doherty, Conor M. Dowling, and Seth J. Hill NBER Working Paper No. 17673

December 2011

JEL No. H0,H1,Z0

\begin{abstract}
Although the secret ballot has long been secured as a legal matter in the United States, formal secrecy protections are not equivalent to convincing citizens that they may vote privately and without fear of reprisal. We present survey evidence that those who have not previously voted are particularly likely to voice doubts about the secrecy of the voting process. We then report results from a field experiment where we provided registered voters with information about ballot secrecy protections prior to the 2010 general election. We find that these letters increased turnout for registered citizens without records of previous turnout, but did not appear to influence the behavior of citizens who had previously voted. These results suggest that although the secret ballot is a long-standing institution in the United States, providing basic information about ballot secrecy can affect the decision to participate to an important degree.
\end{abstract}

\author{
Alan S. Gerber \\ Yale University \\ Institution for Social and Policy Studies \\ 77 Prospect Street \\ New Haven, CT 06520 \\ and NBER \\ alan.gerber@yale.edu \\ Gregory A. Huber \\ Yale University \\ Institution for Social and Policy Studies \\ 77 Prospect Street \\ New Haven, CT 06520 \\ gregory.huber@yale.edu \\ David Doherty \\ Loyola University Chicago \\ Political Science Department \\ 1032 W. Sheridan Road \\ Coffey Hall, 3rd Floor \\ Chicago, IL 60660 \\ ddoherty@luc.edu
}

\author{
Conor M. Dowling \\ Yale University \\ Institution for Social and Policy Studies \\ 77 Prospect St. \\ New Haven, CT 06520 \\ conor.dowling@yale.edu \\ Seth J. Hill \\ $<$ DOM8 QYHWW \\ Institution for Social and Policy Studies \\ 77 Prospect Street \\ New Haven, CT 06520 \\ seth.hill@yale.edu
}


Fair and open elections in which eligible citizens can cast ballots as they see fit are a defining characteristic of legitimate democratic systems. The secret ballot is generally thought of as an essential institution for protecting voters from fear of intimidation or coercion in these contests. ${ }^{1}$ Indeed, in the United States, the adoption of the secret ballot is viewed as a landmark progressive reform. ${ }^{2}$ In this paper, we argue that although the secret ballot has been secured as a legal matter, formal institutions and practices to protect ballot secrecy are not equivalent to convincing citizens that they may vote privately and without fear of reprisal. This distinction between legal protections and beliefs is essential, because it is a citizen's beliefs about electoral institutions — and not the formal operation of those institutions — that will affect her actions. While some previous work has examined the historical consequences of the formal implementation of the secret ballot, little work has considered the potential relationship between beliefs about ballot secrecy and contemporary voting behavior (but see Gerber, Huber, Doherty, and Dowling 2011a).

We provide evidence that, even in the contemporary U.S.- - longstanding democracy that has used the secret ballot for over 100 years—doubts about ballot secrecy are surprisingly widespread. This

\footnotetext{
${ }^{1}$ Indeed, Article 25 of United Nations’ Civil and Political Covenant considers the secret ballot a crucial component of a fair electoral process (Franck 1992, 64).

${ }^{2}$ There is a voluminous literature on the history of the adoption and spread of the Australian (secret) ballot. For example, see Benson (1941), Dowling (2008), Evans (1917), Gerber (1994), Fredman (1968), Rusk (1970), and Wigmore (1889). For related work in the comparative context, see Schaffer (1998) and Stokes (2005). Some scholars have argued that there may have been other motivations for the adoption of the secret ballot (e.g., attempts to entrench a majority party by eliminating the possibility of vote-buying by opposition parties, see Burnham 1970; Kousser 1974) and other consequences of its implementation (e.g., it appeared to benefit incumbents, see Heckelman and Yates 2002; Heckelman 2004, and may have resulted in lower turnout because of the loss of the direct benefits vote-buying provided to voters, see
} Heckelman 1995; 2000). 
long experience coupled with the practice of professional election administration suggest that the United States should be a difficult case for finding such doubts relative to more recent democracies. Despite this long history, we present results from a new opinion survey that shows many Americans have doubts about the secrecy of the ballot and that these doubts are more prevalent among inexperienced citizens (those who have never voted) than among those who have previously participated. Building on the results from this opinion survey, we designed a large-scale, randomized field experiment that was conducted in cooperation with the Connecticut Secretary of State. ${ }^{3}$ This experiment allows us to test the effects of providing registered voters with information about ballot secrecy protections.

We find that beliefs about the secrecy and anonymity of the voting process have real consequences for political participation. In particular, the experiment shows that providing information about the anonymity of the ballot and the protections against intimidation at the polls to those who had not previously voted increased turnout in the November 2010 election by an estimated 3.4 percentage points. This represents a substantial increase in turnout for this group-proportionally the intervention increases turnout by about 20 percent. The estimates of these effects are larger than the estimates of both a placebo intervention that did not include information about ballot secrecy and a similarly designed intervention that emphasized the civic responsibility associated with voting. By contrast, for those who had previously voted, providing information about ballot secrecy protections appears to have negligible effects on participation, particularly when compared to other get out the vote interventions. These differences in effects across groups are consistent with the survey evidence showing doubts about ballot secrecy are more prevalent among those who have not previously voted. They also suggest that doubts

\footnotetext{
${ }^{3}$ None of the costs of this research project were born by the Secretary of State. Partnering with state administrative agencies to assess the effect of information about government procedures is an important contribution of this paper and follows on the work of others (e.g., Blumenthal, Christian, and Slemrod 2001; Slemrod, Blumenthal, and Christian 2001).
} 
about ballot secrecy may discourage political participation for this segment of the population, regardless of how elections are actually conducted within statutory and administrative rules.

Our findings have three broad implications for understanding the nature and consequences of mass behavior. First, we demonstrate the importance of beliefs about political institutions in explaining mass behavior. Institutions may effectively accomplish goals such as protecting the secrecy of the ballot. However, mechanically achieving these goals may not be enough if citizens are unaware of these institutions or do not believe that they work. Our findings suggest that as states and counties across the United States move to implement convenience voting, voting by mail, electronic voting, and other new voting procedures, more careful attention should be paid to not only the design and operation of these new electoral institutions (see, e.g., Alvarez and Hall 2010 on electronic voting), but also to beliefs about each new institution's operation. We show that Americans harbor doubts of meaningful consequence for real political behavior even about the long-standing, well-used, and well-known institution of polling place elections.

A second and related contribution is to show that interventions that focus purely on providing information can allay citizens' (mistaken) beliefs about the operation of institutions and thereby mobilize these citizens. Importantly, our simple intervention mobilized not just any citizen, but a group of eligible citizens who is often targeted by those seeking to increase political participation: those who were registered, but had not previously participated in elections. Efforts to convert these registrants to new voters is a promising step for reducing turnout disparities, particularly given evidence that turnout is itself habit forming (Gerber, Green, and Shachar 2003). Our evidence suggests that providing reassurances about the anonymity and protection of the voting process can bring new voters to the polls, and that these effects are larger than more typical GOTV messages that emphasize the civic responsibility of voting.

Finally, this research is, we believe, an example of successful multi-stage social scientific research. Specifically, by pairing survey findings with a field experiment we are able to demonstrate not only that people voice doubts about ballot secrecy, but that the doubts expressed in the survey context are meaningful and remediable by simple dissemination of basic information. Additionally, comparing the 
effects of these interventions with similar efforts that do not address concerns about ballot secrecy allows us to pinpoint the importance of ballot secrecy concerns in explaining low rates of participation. This project therefore provides a template for combining survey data findings with experimental evidence.

The remainder of the paper proceeds as follows. In the next section we first briefly outline our expectations for how beliefs about ballot secrecy may be associated with political participation. We then discuss our survey results about the nature of doubts about ballot secrecy and our particular interest in those citizens who have never previously voted. Next, we describe our experimental design and then discuss the results of our analysis. The final section identifies some extensions to our work, its limitations, and the broader implications of our findings.

\section{Beliefs about Ballot Secrecy and Political Participation}

Scholarship on turnout in advanced democracies implicitly assumes that the formal institution of the secret ballot is sufficient to remedy any concerns about ballot secrecy that might discourage participation. Despite extensive research on the causes and correlates of turnout, such an assumption has not, to our knowledge, been subject to rigorous empirical review. In the United States, for example, political scientists have offered many explanations for why some citizens do not participate, including individual-level differences (e.g., socioeconomic status [Milbrath and Goel 1977; Wolfinger and Rosenstone 1980], genetics [Fowler, Baker, and Dawes 2008], personality [Gerber, Huber, Doherty, Dowling, Raso, and Ha 2011], political socialization [Campbell, Converse, Miller, and Stokes 1960; Gerber, Green, and Shachar 2003; Plutzer 2002], etc.), campaign effects (e.g., campaign mobilization [Rosenstone and Hansen 1993; Gerber and Green 2000; Green and Gerber 2008], negative campaigning [Ansolabehere and Iyengar 1995; Finkel and Geer 1998], etc.), social pressure (Gerber, Green, and Larimer 2008), and political institutions (e.g., the rules for translating votes into seats [Jackman 1987; Powell 1986], restrictions on who and how individuals may register and vote [Powell 1986; Timpone 1998; Wolfinger and Rosenstone 1980], and the process of voting itself like the availability and location of polling locations [Brady and McNulty 2011]). Although the effects of de jure electoral institutions 
such as registration rules have been investigated, the effects of actual citizen beliefs about the institutions, which may be in conflict with de jure reality, have been the subject of less focus.

In a recent paper however, Gerber et al. (2011a) suggest that formal rules about ballot secrecy may not be sufficient to allay citizen concerns about the voting process. That paper focuses on the implications for vote choice if citizens are concerned about the anonymity of the voting process. Gerber and colleagues contend that the decisions people make in the voting booth may be affected by social or group influences if they believe those choices may be revealed (through either monitoring of how they fill out their ballot or, after the fact, by matching the cast ballot to their name), a common factor noted in explaining voter decision-making in the pre-secret ballot era (e.g., Bensel 2004; Bishop 1893).

What has received less attention in prior work is that fears about a lack of secrecy may also deter political participation. ${ }^{4}$ Although previous research suggests that the social consequences of failing to participate may play an important role in encouraging turnout (e.g., Gerber, Green, and Larimer 2008; Gerber, Huber, Doherty, and Dowling 2011b), if citizens have doubts about the voting process, then the perceived threat of social consequences may also depress turnout. For example, citizens may worry that they will suffer direct sanctions for the choices they make when voting if those choices are revealed and instead choose to shield themselves from these sanctions by staying home on Election Day. Similarly, doubts about secrecy may cause voters to think that the process of voting involves direct conflict, possible embarrassment, or intimidation — that when voting they will have to justify their choices or will be challenged by those who disagree with them. Such potential conflict or stress can be avoided by abstention. These dynamics may be an example of the ways in which the powerful act to entrench themselves by suppressing the expression of discontent in the first place (e.g., Bachrach and Baratz 1962; Gaventa 1982).

\footnotetext{
${ }^{4}$ Heckelman (1995) contends that the adoption of the secret ballot in the U.S. may have diminished turnout historically because, without the ability to verify vote choices, secrecy eliminated the ability of parties and candidates to offer payments (bribes) to voters for voting for a particular candidate.
} 
Although views about a lack of ballot secrecy are expressed in survey data by around one quarter of the population (Gerber et al. 2011a), a key question is whether these beliefs are real and consequential. On the one hand, survey responses indicating doubts about secrecy, because they are costless to express, may be efforts by non-voters to justify lack of participation. On the other hand, those beliefs may be real but uncorrectable or irrelevant—even after being told that voting is secret, these citizens may not change their attitudes or might still stay home for other reasons. We investigate both possibilities.

\section{New Survey Evidence on Beliefs about Ballot Secrecy}

Building on Gerber and colleagues' earlier work, we fielded a survey after the 2010 midterm election to assess citizens' beliefs about the process of voting, both generally and with respect to ballot secrecy concerns. ${ }^{5}$ The results suggest that concerns about ballot secrecy are particularly widespread among those who have never voted. The survey asked respondents who reported having ever voted a series of questions about their experience the last time they voted. Those who had never voted before were asked analogous questions about their expectations for what the voting experience would be like if they were to vote. In Figure 1, we summarize responses to four of the questions we asked, which are representative of the entire set of questions we asked. The figure displays the proportion of respondents (weighted to reflect a national sample) who responded "Yes” (white part of the bars), "Don’t Know” or "Don’t Remember” (light gray part of the bars), and "No" (dark gray part of the bars) to each statement, broken down by whether they reported having ever voted. ${ }^{6}$

[Figure 1 About Here]

\footnotetext{
${ }^{5}$ Polimetrix/YouGov completed on our behalf a survey of a nationally representative sample of 3,000 citizens 25-years and older in the month following the November 2010 election.

${ }^{6}$ Among ever-voters, the sample is restricted to those whose last reported vote was in person (early or on Election Day). Nineteen percent of survey respondents reported voting absentee, by mail, or could not recall how they last voted.
} 
These data show that those who report never having voted before are more likely than those who report having voted to believe (1) that they would write their name on their ballot (13 versus 6\% among all respondents), (2) that some information on their ballot could be used to match it to them after the fact (20 versus 11\%), (3) that someone at the polling place would ask them who they voted for (12 versus $3 \%$ ), and (4) that a poll worker would be able to see who they voted for (8 versus 3\%). We also note that for each item, over one-third of non-voters gave a “Don’t Know” response, and that these responses also suggest doubts and uncertainty about the secrecy of the voting process. In this light, if we restrict our attention to those who offered a "Yes" or "No" response to the questions displayed in Figure 1 the differences between Ever-Voters and Non-Voters are even more stark. Specifically, the percentages responding "Yes” (of "Yes” and “No” responses) to each of the four items are for Never-Voters and EverVoters, respectively, (1) 20 versus 6\%, (2) 32 versus 13\%, (3) 20 versus 3\%, and (4) 12 versus 3\%. In sum, the findings presented in Figure 1 broadly suggest that those who do not have experience voting are substantially less likely to believe that the ballots voters cast are anonymous and more likely to believe that voters may divulge their choices to people they encounter at the polling place. These perceptions, which are interesting in their own right, may help to explain their lack of participation on Election Day.

An extant experimental literature highlights the importance of social and experiential concerns, like the ones we suggest may operate here, in explaining participation. For example, Addonizio (2004) shows that exposing inexperienced voters (high school students) to the process of voting by having them walk through a mock polling place and practice voting increases subsequent turnout. This effect is consistent with non-voters being dissuaded from participating by lack of knowledge of the process, which may include beliefs that one's vote will not be kept secret. Other work finds that making the negative social consequences of being revealed as not having voted more salient increases participation (Gerber, Green, and Larimer 2008; follow-on work includes Davenport 2010; Davenport, Gerber, Green, Larimer, Mann, and Panagopoulos 2010; Gerber, Green, and Larimer 2010; Mann 2010; Panagopoulos 2010). ${ }^{7}$

\footnotetext{
${ }^{7}$ This focus on revealing whether someone has complied with a positive social norm is in contrast to a
} 
What remains unknown is whether directly addressing doubts about ballot secrecy would alter voter behavior.

\section{Experimental Design}

In order to investigate whether beliefs about ballot secrecy affect the decision to participate, we designed and implemented a randomized field experiment in Connecticut during the 2010 midterm election. To assess the particular importance of beliefs about ballot secrecy on turnout, we implemented a variety of interventions, each of which was a mailing that conveyed different information. The design included both a non-treated (no mailing) control group and a set of placebo treatments, which we detail below. Our outcome of interest is participation in the 2010 general election held on November 2, 2010. We measure participation using turnout as recorded in the Connecticut voter file.

The theory and survey evidence outlined above suggest that individuals who have not previously participated are most likely to hold beliefs about ballot secrecy that would deter participation. To the extent that these beliefs are incongruent with the experiences of voters and the practice of professionalized election administration, we hypothesize that delivering corrective information might reduce concerns about the secrecy of the voting process and increase the likelihood of voting. For this reason, we stratified our experimental design to allow us to more precisely estimate the effects of information about ballot secrecy on those active Connecticut registrants who have not previously voted. We also assess the effects of our treatments on those who had previously voted to test our assumption that beliefs about secrecy were most important for current non-voters.

field experiment reported in Grose and Russell (2008). Grose and Russell find that telling voters before the Iowa Caucus that their vote in the caucus is not secret reduces turnout by about 22 percentage points relative to an identical treatment that emphasizes that their friends and neighbors will also be present but lacks the information about voting not being secret ( $\mathrm{N}=232$ for these two treatments). Among potential caucus goers, this suggests that being reminded of the potential for open disagreement with neighbors and friends in one’s party reduces turnout. 
The experiment proceeded in four stages, each of which is detailed in Table 1. In Stage 1 we identified our eligible sample, beginning with a list of all voters in the Connecticut voter file produced by the Connecticut Secretary of State in June 2010. From this list we removed all individuals who 1) were listed as inactive, 2) lacked a valid current Connecticut mailing address (including failing to pass a National Change of Address [NCOA] filter), or 3) had their mail delivered to a post office box. ${ }^{8}$ The first restriction removes registrants who were ineligible to vote. The latter restrictions focus on making sure recipients would be likely to receive a mailing sent in the days preceding the election. Similarly, we eliminated any voter who voted by absentee ballot in 2006, 2008, or 2010 because many of these individuals may have already voted at the time the mailing was sent. We also removed any registrants less than 18 years of age or over the age of 85 out of concern that they would be unlikely to participate.

Finally, we removed records from households with more than five registrants at a single address because these individuals are likely to live in temporary (e.g., school dorms) or group housing where mail would be less likely to be delivered on time. From this pool of eligible registrants, if there were multiple eligible registrants from a single household (address), we randomly selected a single representative registrant. This sampling procedure yielded 894,791 eligible registrants in unique households.

[Table 1 About Here]

In Stage 2 we identified our three treatment strata and assigned treatments. Each stratum is a stand-alone group of registrants on which the experiment is run, allowing us to estimate separate treatment effects for each group. Our first stratum is recent registrants- those who registered after the 2004 general election — who had never voted. We label this stratum recently registered non-voters. The second stratum is earlier registrants (registered prior to the 2004 general election) who had also never voted. We label this stratum longstanding registered non-voters. We believe that those who had not

\footnotetext{
${ }^{8}$ The United States Postal Service provides a National Change of Address service that checks a name and address against the USPS list of changed addresses. This service, provided for fees by licensees, helps reduce undeliverable mailings.
} 
previously participated are most likely to hold concerns about election administration that deter participation. However, we separate these non-voters into two groups for reasons of efficiency: Those who registered prior to 2004 but have never voted are less likely to reside now at the address listed on the voter file. $^{9}$

We define our third stratum as those who were listed to have ever voted in any election in the voter file. We label this stratum ever-voters. Recently registered non-voters make up about 9 percent of our targeted sample, longstanding registered non-voters about 9 percent, and ever-voters the remaining 82 percent. Although we ran all registrants for the first two strata through the NCOA list, for reasons of cost we randomly selected a subset of ever-voters to verify their addresses. Our sample of registrants that passed the NCOA check is 69,488 recently registered non-voters, 68,859 longstanding registered nonvoters, and 18,586 ever-voters. For each of the three strata, summary statistics for all demographic covariates available in the voter file appear in Appendix Table A1. ${ }^{10}$

Consistent with their status as recent registrants who have never voted, the most notable difference across strata in demographics is that recently registered non-voters are much younger than those in the other strata (their average age is only 38, relative to 52 among the ever-voters). Along with

\footnotetext{
${ }^{9}$ These registrants are also more likely to have moved prior to the 18 month retrospective window covered by the NCOA review. Additionally, we have also since learned that local party organizations in some jurisdictions may have been motivated to keep these registrants on the rolls even if they were no longer physically present in order to increase their representation in the state party organizations where positions are assigned, in part, on the basis of the number of party registrants in each jurisdiction.

${ }^{10}$ All variables used for our stratum definitions are derived from the Connecticut statewide voter file, so to the extent there exist inaccuracies in the file, measurement error is introduced. We note, however, that the most likely error is that previous voters who re-registered may not have been linked to their prior vote history records. If this is the case, then to the extent we have misclassified ever-voters as non-voters our findings about non-voters are biased toward those for ever-voters.
} 
this difference in age, they are less likely to live in a two-person voter household. Also consistent with their records in the voter file being newer, they are less likely to have their gender listed as missing. Finally, they are less likely than either longstanding registered non-voters or ever-voters to have affiliated with either the Democratic or Republican Parties.

In Stage 3, we randomly assigned each registrant to one of eight conditions within each stratum. ${ }^{11}$ Each treatment was a letter, described in greater detail below. Letters were mailed on October 28 to arrive between October 29 and November 1, approximately 1 to 4 days prior to the election. We sent a total of 16,556 treatment letters. In order to enable us to detect small effects in our primary target stratum (recently registered non-voters), we significantly under-weighted the share of the feasible treatments sent to longstanding registered non-voters in favor of treating a larger share of the recently registered nonvoters. We allocated approximately 32 percent $(5,357)$ of our treatments to the recently registered nonvoters stratum (a within stratum overall treatment rate of 7.7 percent). We assigned 5 percent (836) of the treatments to the longstanding registered non-voters stratum (a treatment rate of 1.2 percent) and 63 percent to the much larger ever-voters stratum (a treatment rate of 55.8 percent of the ever-voters checked against the NCOA list). Balance statistics (summary statistics for all demographic variables) for control and each treatment group in all strata appear in Table 2 (recently registered non-voters in Table 2a, longstanding registered non-voters in Table 2b, and ever-voters in Table 2c). To test for observable differences between treatment and control groups we performed a multinomial logit for each strata using information available at the time of treatment assignment to predict assignment. We compared the chisquare test statistic for the joint significance of all variables available at the time of assignment to the

\footnotetext{
${ }^{11}$ Within each stratum, randomization took place within blocks. Subject to rounding, equal proportions were assigned to treatments across blocks in each stratum. In all strata, we blocked on residence for the 6 largest towns (plus a remainder category for respondents not living in those towns). For the two strata composed of those who had never voted, we also blocked on age (in 5 year increments). In the ever-voters stratum, we also blocked on vote history in the 2004, 2006, and 2008 general elections.
} 
distribution of the statistic across a set of 2000 bootstrapped alternative random treatment assignments to conduct an exact randomization test. The p-value for the location of the test statistic in the distribution of test statistics from the randomization test appears at the bottom of Tables 2a, 2b, and 2c. We present the full distribution of the bootstrapped test statistics in Appendix Figure A1. A detailed summary of treatment assignment counts by strata appears in Table 3.

[Tables 2 and 3 About Here]

\section{Description of Treatments}

We partnered with the Connecticut Secretary of State to send informational letters to our sampled registered voters. Six of our seven treatment letters appeared on Secretary of State letterhead. Our primary interest is in how perceptions of ballot secrecy influence participation, and three of our treatment letters addressed concerns about ballot secrecy. The first, SOS Secrecy 1 (Anonymity), was sent on Secretary of State letterhead and emphasized how the choices a voter made in the voting booth would be kept secret by including the following text:

We maintain the secrecy of the ballot. Poll workers keep only a list of who voted, not how they voted. No record of how you or any other voter filled out their ballot is created other than your anonymous ballot. Your choices cannot be matched up with your name. Additionally, voting booths provide a private place for you to fill out your ballot. You place your ballot into the voting machine on top of the locked ballot box without anyone else looking at it.

The second treatment letter, SOS Secrecy 2 (No Intimidation), was similar to the first intervention but emphasized a different element of secrecy in the voting process. It focused on the fact that voters are not required to reveal or explain their choices to poll workers and that campaigns cannot be active in polling places. In place of the paragraph listed above, it read:

We make sure that you can vote free from intimidation. A set of rules is enforced at each polling place to ensure that voters are comfortable casting votes for whomever they prefer. For example, poll workers are not permitted to ask who you voted for, and campaigning is prohibited inside of or near polling places.

Finally, the third secrecy intervention, SOS Secrecy Combined, included both paragraphs of text from the SOS Secrecy 1 (Anonymity) and SOS Secrecy 2 (No Intimidation) treatments. Because each argument 
addresses a different area of concern, it was our expectation that the combined effect of this mailing would be larger than the effect of each of the two interventions alone.

Because of random assignment, comparing individuals assigned to the control group with those sent each of the letters that addresses secrecy concerns yields an unbiased estimate of the effect of those interventions. However, one concern is that if these letters are effective in increasing turnout, it may not be because of their particular content concerning ballot secrecy. Each letter was addressed to the individual registrant on Secretary of State letterhead and also included information that there was an election occurring on November 2, 2010. In order to help isolate the effects of information about ballot secrecy from the effect of receiving election-related mail from the Secretary of State, we also fielded two "placebo" treatments. SOS Short, which was also sent on Secretary of State letterhead, is identical to the three secrecy letters but lacks any text addressing concerns about ballot secrecy.

Because it lacks any text addressing ballot secrecy concerns, the SOS Short letter is shorter than any of the secrecy letters. To ensure that any differences in treatment effects were not due to the amount of text, we also fielded SOS Control, which is a longer version of SOS Short with information about the role of the Secretary of State in election administration unrelated to ballot secrecy. ${ }^{12}$ In particular, it included this text:

We implement state and federal laws. The Legislation and Elections Administration Division of the Office of the Secretary of State administers, interprets, and implements all state and federal laws pertaining to elections, primaries, and nominating procedures. We also oversee the acquisition and exercise of voting rights, and supervise the statewide tabulation of voting results after each election.

We assist elected officials. Along with local Town Clerks and Registrars of Voters, my office provides training for local elected officials. In addition, our office is the official keeper of all acts, orders, grants and resolutions of the General Assembly. We also receive and maintain legislation, regulations, and a wide range of other public documents.

We note that, like the secrecy interventions, this letter makes clear the SOS office's interest in election administration.

12 This text was produced based on information available on the office of the Connecticut's Secretary of State’s public website. 
Our last two treatments are the SOS Civic Duty and Generic Civic Duty letters. SOS Civic Duty

adds to the SOS Short letter standard text focusing on the civic duty associated with voting:

Voting is a right and responsibility. I want to remind you to exercise your right to vote this November. The right to vote is an important American tradition. The whole point of democracy is that citizens are active participants in government and democracy functions best when everyone takes part in the voting process. This November, remember your rights and responsibilities as a citizen.

Your voice starts with your vote. Voting is one of the most important ways citizens have to make their voices heard. By taking the time to do their civic duty, voters ensure that elected leaders know what they think and how they feel. I encourage you to take the time to fulfill your civic duty by voting on November $2^{\text {nd }}$.

This is a standard GOTV intervention and is typically associated with a less than one percentage point increase in turnout in midterm elections (Green and Gerber 2008). As such, we use it to compare the effects of the secrecy interventions to a more standard GOTV appeal. The text of Generic Civic Duty is identical, but is sent under cover of “Connecticut Votes” rather than the Secretary of State. ${ }^{13}$

We gathered information about participation in the 2010 election from an updated Connecticut voter file from February of 2011. For participants listed in this voter file, turnout was coded 1 if the respondent voted in the 2010 general election and 0 if not. For respondents who were no longer listed in the updated voter file, turnout was coded $0 .{ }^{14}$ In Figure 2, we present a diagram describing the design of the experiment from sample definition through population filters and random assignment. ${ }^{15}$

\footnotetext{
${ }^{13}$ Comparing these last two treatments allows us to assess whether there are any increased mobilization effects associated with mail delivered under the Secretary of State's letterhead relative to a nongovernmental GOTV group, an analysis we conduct in other work.

${ }^{14}$ Excluding the 507 out of 894,791 registrants in our target population who did not match to the postelection file, rather than coding their turnout as zero, does not substantively change any of the results presented.

${ }^{15}$ We collected and recorded each mailed treatment letter returned as undeliverable by the US Postal Service — 780 of 16,556 (4.7\% of) mailed letters were returned. Analysis restricted to those respondents whose mail (i.e., excluding the control group, comparing across treatments) was not returned produces
} 
[Figure 2 About Here]

\section{Analysis}

Our analysis proceeds in two stages. We begin by comparing, for each stratum, the effect of receiving any of the individual secrecy mailings to being in the control group, to which no mail was sent. This analysis employs the entire sample for which treatment randomization took place. Next, we compare the effect of receiving any of the three secrecy mailings to the effect of the other (placebo) SOS mailings and to the civic duty mailings. These comparisons showing the relative effectiveness of the secrecy messages are necessarily limited only to those sent letters. Our results show that informing voters of the formal institutional protections of ballot secrecy increased participation among registrants who had not previously voted, but had negligible effects on those who had previously voted. The positive estimated effects of the secrecy intervention among inexperienced voters hold when comparing them to the control group and to either a civic duty intervention or to a placebo intervention with non-secrecy content.

\section{The Effects of Information About Ballot Secrecy}

Table 4 shows 2010 turnout by control and treatment assignment for each stratum. As one might expect given the habitual nature of voting and the definitions we use for our three strata, in the control group we find that turnout is 62.6 percent among ever-voters, substantially higher than recently registered non-voters (17.0 percent), which is higher still than turnout among longstanding registered non-voters (13.2 percent). Table 4 also indicates that the secrecy interventions increased turnout. Recently registered non-voters sent a secrecy letter voted in 2010 at rates 2.8 to 4.1 percentage points higher than those assigned to the control condition (a proportional increase of 16 to 24 percent for this stratum). Among longstanding registered non-voters, turnout is .2 to 4.3 percentage points higher for those sent secrecy letters than those in the control group (a proportional increase of 2 to 33 percent). The effect is .1 to 1.2 percentage points among ever-voters (0 to 2 percent proportional). In short, the effects of the secrecy letters appear to be larger for non-voters.

similar results. Results are available upon request. 
[Table 4 About Here]

By contrast, the effects of the two placebo letters, SOS Control and SOS Short, are small for both recently registered non-voters (-.2 and -.7 percentage points, respectively) and longstanding registered non-voters (-3.1 and 1.1 percentage points, respectively). Among the ever-voters stratum, these two treatments each have a 2.4 percentage point effect relative to the control group. The SOS Civic Duty and Generic Civic Duty treatments also present modest effects relative to the control group across strata: 1.2 and .6 percentage points among the recently registered non-voters, -2.0 and -2.5 for longstanding registered non-voters, and -.5 and 1.6 for ever-voters.

We are able to detect a positive and statistically significant effect of the secrecy interventions on turnout in the recently registered non-voters stratum in our experiment. Difference-of-means tests are statistically significant for all three secrecy letters relative to the control condition $(p=.04, .002$, and .009 for SOS Secrecy 1 (Anonymity), SOS Secrecy 2 (No Intimidation), and SOS Combined, respectively). We find no statistically distinguishable difference among longstanding registered non-voters or ever-voters. ${ }^{16}$ We now turn to regression models to formalize these differences and to test for robustness to the inclusion of pre-treatment covariates, but note that regression results are consistent with the simple differences of means.

In Table 5 we estimate parallel OLS regression models with robust (Huber/White) standard errors for each stratum. Our basic models estimate the effects of the randomly assigned treatments with no control variables (odd numbered columns), with a subsequent specification using measures from the voter file as covariates (even numbered columns). ${ }^{17}$ In columns (1)-(6), the excluded category is assignment to

\footnotetext{
${ }^{16}$ The p-values on difference of means tests comparing any of the three secrecy interventions (e.g., pooling the three treatments to form a single group) to either of the SOS Placebo interventions (pooling the placebo treatment groups into a single group) are .003 (recent registered non-voters), .330 (longstanding registered non-voters), and .181 (ever-voters).

${ }^{17}$ For space reasons, Table 5 does not report the coefficients and standard errors for the voter file
} 
the control condition-individuals in our target population randomly assigned to receive no mailing of any kind.

Focusing first on the results for recently registered non-voters in column (1), we find that the secrecy intervention increased turnout by between 2.8 and 4.0 percentage points relative to turnout in the control group with all three coefficients statistically significant at $\mathrm{p}<.05$. No other treatments have statistically significant effects in this stratum, and each of the secrecy interventions has a larger effect than the effect of any of the other treatments. ${ }^{18}$ The results are virtually unchanged with the addition of the measures from the voter file as covariates in column (2).

Our longstanding registered non-voters stratum has a much smaller number of cases assigned to each treatment condition. The results reported in columns (3) and (4) reflect the small sample sizes with large standard errors. The pattern of findings is consistent with the notion that, as with the recently registered non-voters, messages based on secrecy concerns are especially effective for this subgroup. However, the estimates are imprecise. The only statistically significant $(\mathrm{p}<.10)$ coefficient is for the SOS Secrecy Combined treatment, with a point estimate of 5.7 percentage points in column (4). The other secrecy treatments have smaller positive effects—-from 1.3 to 2.3 percentage points in column (4)—but are not statistically significant. The largest point estimate for any other treatment is less than 1 percentage point.

Finally, among ever-voters (columns [5] and [6]), the only statistically significant $(\mathrm{p}<.10)$ effect is a 2.4 (column [5]) to 2.5 (column [6]) percentage point increase in turnout for the SOS Short intervention. The secrecy interventions are estimated to increase turnout by between .2 and 1.3 percentage points in column (6), but none of these effects are statistically distinguishable from zero.

measures; Appendix Table A2 presents the full model results.

${ }^{18}$ The SOS Civic Duty and Generic Civic Duty treatments are associated with 1.2 and .5 percentage point increases in turnout, consistent with the results of published field experiments. These effects are not statistically distinguishable from zero in our sample, however. 
[Table 5 About Here]

Overall, these results suggest that the secrecy letters increased the propensity to vote among those citizens who are legally registered to turn out but have no record of previously exercising that right (members of both the recently registered non-voters and the longstanding registered non-voters strata). Relative to not being sent any intervention, mailings that emphasized the protections available for ballot secrecy increased turnout by a statistically significant 16 to 24 percent among recently registered nonvoters, with similar but less precisely estimated effects among longstanding registered non-voters. For those who had ever voted, the secrecy interventions had much smaller effects that are statistically indistinguishable from zero. The question remains as to whether these effects originate in secrecy concerns per se, or are instead the result of the fact that our interventions involved contact from an important government official and conveyed information about the upcoming election. For this reason, our next set of comparisons focuses on differences in outcomes between the secrecy interventions and the other interventions.

\section{Ballot Secrecy Effect Relative to Other Letters}

To isolate the effects of the content of the different treatment letters, we now examine differences in turnout across the different treatment letters. In columns (7) through (12) of Table 5, we repeat our earlier statistical analysis but now include only those respondents sent one of the secrecy interventions or either of the placebo interventions sent on SOS letterhead (SOS Short and SOS Control). As there is no statistically significant difference between the two SOS placebo treatments in any strata in columns (1)(6), we pool these treatments and use them as the excluded comparison category (we refer to those pooled treatments as SOS Placebo). Additionally, we pool the three secrecy treatments (SOS Secrecy 1 (Anonymity), SOS Secrecy 2 (No Intimidation), and SOS Secrecy Combined) into Any Secrecy Treatment, coded 1 for an individual assigned to any of the three secrecy interventions. Thus, the coefficient for Any Secrecy Treatment is the effect of assignment to any of the three secrecy letters relative to the effect of assignment to either SOS Placebo. 
Comparing Any Secrecy Treatment to SOS Placebo is particularly compelling because the two placebo messages allow us to distinguish the effect of the secrecy content from both (1) contact by the Secretary of State and (2) the communication of information about the upcoming election and the Secretary’s efforts in overseeing and administering election rules. The statistically significant .039 and .038 coefficients $(\mathrm{p}<.01)$ on Any Secrecy Treatment in columns (7) and (8) indicate that among the recently registered non-voters the average effect of the secrecy interventions was to increase turnout by about four percentage points relative to the average effect of the two SOS placebo messages. Overall, this is a substantial increase in turnout for a relatively straightforward set of interventions that communicate factual information about the voting process to inexperienced voters. Additionally, the fact that the secrecy interventions each have larger point estimates than either the SOS Civic Duty or Generic Civic Duty messages (in columns [1] and [2]) implies that addressing secrecy concerns is not increasing turnout simply by making voters believe they have a greater obligation to vote.

Turning to the other two strata, among the longstanding registered non-voters (columns [9] and [10]) the effect of Any Secrecy Treatment is roughly similar to that for recently registered non-voters, 3.0 in column (9) without covariates and 4.4 percentage points in column (10) with covariates, but is not statistically distinguishable from the effects of the placebo treatments. Finally, among ever-voters, the effect of Any Secrecy Treatment is a negative 1.6 (1.4) percentage points relative to the placebo messages in column (11) (column [12]), but this effect is also not statistically significant ( $\mathrm{p}=.18$ and .19). The effects among recently registered non-voters appear distinct from those among ever-voters, with confidence intervals on the effects that do not overlap. ${ }^{19}$ It is interesting that for experienced voters, we find that the two placebo messages are associated with the largest increase in turnout relative to the

\footnotetext{
${ }^{19}$ Ninety-five percent confidence intervals for the Any Secrecy Treatment coefficient in the non-covariate specifications in columns (7) and (11) of Table 5 are [1.34, 6.51] and [-3.9, 0.73], respectively.
} 
control (see columns [5] and [6]). These placebo interventions mentioned the upcoming election and (for the SOS Control letter) the Secretary of State’s responsibilities in helping to administer elections. ${ }^{20}$

Finally, we consider whether there is any evidence that the effect of the secrecy interventions follows a dose-response pattern among recently registered non-voters (small cell sizes make comparisons for longstanding registered non-voters infeasible). Direct inspection of the coefficients in column (2) of Table 5 suggests that the combined effects of the two secrecy arguments from SOS Secrecy 1 (Anonymity) and SOS Secrecy 2 (No Intimidation) in SOS Secrecy Combined do not generate a cumulative effect equal to the sum of the individual messages. The combined message increases turnout by only 1 percentage point relative to SOS Secrecy 1 (Anonymity) and only .3 percentage points relative to SOS Secrecy 2 (No Intimidation). More formally, testing whether the coefficient(s) on (SOS Secrecy 1 (Anonymity) + SOS Secrecy 2 (No Intimidation)) - SOS Secrecy Combined is equal to zero yields a p-value of .28. Thus, although we cannot rule out (statistically) the possibility that the effect of the combined treatment is equal to the sum of the individual treatments, the sum of the coefficients on the SOS Secrecy 1 (Anonymity) and SOS Secrecy 2 (No Intimidation) is 2.6 percentage points greater than the coefficient on the SOS Secrecy Combined variable and 68\% larger than that coefficient.

In sum, the regression results replicate the difference of means results in Table 4 . We find that letters providing information about the formal and administrative protections of the ballot increase turnout. These effects are statistically significantly larger than the effects of other election correspondence from the Secretary of State; the effects are also larger than (but not statistically distinguishable from) the effects of standard civic duty appeals. When compared to a placebo intervention letter also sent from the

\footnotetext{
${ }^{20}$ By contrast the SOS Civic Duty message is associated with a -.9 percentage point decrease in turnout relative to control, which is a -3.3 (with rounding) percentage point effect relative to the SOS Short placebo message ( $\mathrm{p}=.043$ ). The SOS Civic Duty letter is identical to the SOS Short letter with the addition of text emphasizing the civic duty associated with voting. We offer no speculation as to why experienced voters might have reacted negatively to this effort to promote the civic duty of voting.
} 
Secretary of State about the election, but providing information about the election other than about the secrecy of the ballot, we find that the effect of the secret ballot treatment is limited to registrants who had not previously voted, while registrants who had previously voted appear to be no more responsive to secrecy information than to other election information from the Secretary of State.

\section{Discussion}

In this research we used a multi-stage research design to examine public perceptions about ballot secrecy as well as whether those registered voters most likely to have doubts about secrecy are more likely to vote after being provided with information about the voting process. Our survey evidence shows that despite the formal institutional practice of government supervised and administered elections with longstanding protections for ballot secrecy, many people say they harbor doubts about the secrecy of the voting process. These doubts are particularly concentrated among those who have not voted before. The findings from the field experiment suggest a relationship between doubts about ballot secrecy and the decision to participate in elections in the contemporary United States. We find that an intervention providing simple information about ballot secrecy protections increased participation among recent registrants who have not previously participated. The magnitude of this effect was substantial and larger than the effects typically found for a single GOTV mailing. While only $17.0 \%$ of the individuals in this group who were not sent a letter turned out to vote, $20.4 \%$ of those sent a letter containing information about ballot secrecy protections turned out-a proportional increase of 20\%. Taken together, our survey and field experiment findings are consistent with the argument that the beliefs about secrecy that people express in surveys are both real and somewhat remediable —-when these doubts are addressed, participation increases among this group.

More broadly, this work illustrates that an important area for research is to understand the sources and consequences of beliefs about the operation of political institutions. Our findings suggest that beliefs about how a political institution works can be politically consequential, even if they are at odds with the reality of how that institution operates. We note that our focus on beliefs about ballot secrecy in the context of elections in the contemporary United States is in many ways a “difficult case.” In countries 
with new electoral institutions, doubts about secrecy may be more prevalent and depress turnout, even in cases where the institutions are well-designed and properly implemented. Therefore, an especially promising avenue for research deals with beliefs about the operation of electoral institutions in other countries.

Similarly, our findings suggest that in order to understand how changes to election procedures in the U.S. and other long-standing democracies affect behavior, it is important to consider how the public understands the new institution. Evidence from our field experiment suggests that sending letters that provide simple information about the secrecy of the voting process may correct errant perceptions about that process and thereby substantially increase turnout among a group of individuals who are typically difficult to mobilize - those who are registered to vote but have not voted before. This specific informational intervention is unlikely to be the only such intervention that can motivate participation for those groups that currently abstain from voting in elections. If comparable misperceptions about other institutional procedures exist, they too may have important consequences for patterns of participation. Remedying such misperceptions is particularly important given that these beliefs may be self sustainingsomeone who chooses not to participate because they doubt the secrecy of the ballot effectively shields herself from learning about secrecy protections by failing to engage in the voting process. Similarly, someone who doubts votes for the opposition are counted fairly may choose not to vote, ensuring that fewer votes for the opposition are cast, which, even if elections are conducted properly, may reinforce doubts about the legitimacy of election institutions and further deter participation.

The treatment effects we find originating in a single letter sent in the days before an election might be a lower bound relative to the effect of a more sustained and broad-based public education campaign. An area for subsequent research would be to examine the effect of embedding education about ballot secrecy into voter registration initiatives so as to directly address any mistaken beliefs ahead of time. One could also conduct standard opinion surveys before and after any such intervention to assess changes in these attitudes and measure the relative contribution of changes in secrecy attitudes to changes in participation. Indeed, one remaining question is whether doubts about secrecy are an impediment to 
registering in the first place. Our experiment only includes registrants (because only they are eligible to vote). It could be the case that the interventions we used would be even more consequential among those who have previously been unwilling to even register.

Additional areas for ongoing research include whether the effects of addressing doubts about ballot secrecy generate a persistent change in behavior and affect other registrants in the voter's household. Regarding the former, if doubts about ballot secrecy do stem from lack of information about how elections are conducted, then addressing those concerns should permanently remove a persistent barrier to participation and yield long term changes in patterns of participation. Examining how our treatments and similar treatments affect participation in subsequent elections is a natural next step.

Finally, there are questions of generalizability and replicability. Given the size of our experiment and the use of random assignment, it is unlikely that our estimates of treatment effects are entirely spurious. However, one should also be cautious in assuming that similar results would hold in other states and in other electoral contexts (e.g., presidential or purely local elections). Beliefs about secrecy may also vary, even among inexperienced voters, based on things such as generational experiences with technology or observing shared public events that affect generational beliefs. Repeating this experiment in other states and including non-registrants will be important for measuring the importance and robustness of this effect. These caveats aside, the data presented here indicate that beliefs about ballot secrecy may be an important and unrecognized, yet potentially remediable, barrier to political participation in the United States. 


\section{References}

Addonizio, Elizabeth. 2004. "Reducing Inequality in Political Participation: An Experiment to Measure the Effects of Voting Instruction on Youth Voter Turnout.” Presented at the Annual Meeting of the American Political Science Association, Chicago.

Alvarez, R. Michael, and Thad E. Hall. 2010. Electronic Elections: The Perils and Promises of Digital Democracy. Princeton, NJ: Princeton University Press.

Ansolabehere, Stephen, and Shanto Iyengar. 1995. Going Negative: How Political Advertisements Shrink and Polarize the Electorate. New York: Free Press.

Bachrach, Peter and Morton S. Baratz. 1962. “Two Faces of Power.” American Political Science Review 56: 947-952.

Benson, Lawrence E. 1941. “Studies in Secret-Ballot Technique.” Public Opinion Quarterly 5: 79-82.

Bensel, Richard F. 2004. The American Ballot Box in the Mid-nineteenth Century. New York: Cambridge University Press.

Bishop, Cortlandt F. 1893. History of Elections in the American Colonies. New York: Columbia College.

Blumenthal, Marsha, Charles Christian, and Joel Slemrod. 2001. "Do Normative Appeals Affect Tax Compliance? Evidence from a Controlled Experiment in Minnesota.” National Tax Journal 54: 125-138.

Brady, Henry E., and John E. McNulty. 2011. “Turning Out to Vote: The Costs of Finding and Getting to the Polling Place.” American Political Science Review 105: 115-134.

Burnhan, Walter. 1970. Critical Elections and the Mainsprings of American Politics. New York: W.W. Norton.

Campbell, Angus, Philip Converse, Warren Miller, and Donald Stokes. 1960. The American Voter. New York: Wiley.

Davenport, Tiffany C. 2010. "Public Accountability and Political Participation: Effects of a Face-to-Face Feedback Intervention on Voter Turnout of Public Housing Voting Behavior.” Political Behavior 32: 337-368.

Davenport, Tiffany C., Alan S. Gerber, Donald P. Green, Christopher W. Larimer, Christopher B. Mann, and Costas Panagopoulos. 2010. "The Enduring Effects of Social Pressure: Tracking Campaign Experiments Over a Series of Elections.” Political Behavior 32: 423-430.

Dowling, Conor M. 2008. "The Costs of Running for Office: How Electoral Campaign Laws Structure Candidate Entry in U.S. Elections.” Ph.D. diss. Binghamton University (SUNY).

Evans, Eldon C. 1917. A History of the Australian Ballot System in the United States. Chicago: The University of Chicago Press.

Finkel, Steven, and John Geer. 1998. "A Spot Check: Casting Doubt on the Demobilizing Effect of Attack Advertising.” American Journal of Political Science 42: 573-595. 
Fowler, James H., Laura A. Baker, and Christopher T. Dawes. 2008. "Genetic Variation in Political Participation.” American Political Science Review 102: 233-248.

Franck, Thomas M. 1992. “The Emerging Right to Democratic Governance.” American Journal of International Law 86: 46-91.

Fredman, Lionel E. 1968. The Australian Ballot: The Story of an American Reform. East Lansing, MI: Michigan State University Press.

Gaventa, John. 1982. Power and Powerlessness: Quiescence and Rebellion in an Appalachian Valley. Urbana, IL: University of Illinois Press.

Gerber, Alan S. 1994. “The Adoption of the Secret Ballot.” Ph.D. diss. Massachusetts Institute of Technology.

Gerber, Alan S., Donald P. Green, and Christopher W. Larimer. 2008. "Social Pressure and Voter Turnout: Evidence from a Large-Scale Field Experiment.” American Political Science Review 102: 33-48.

Gerber, Alan S., Donald P. Green, and Christopher W. Larimer. 2010. “An Experiment Testing the Relative Effectiveness of Encouraging Voter Participation by Inducing Feelings of Pride or Shame.” Political Behavior 32: 409-422.

Gerber, Alan S., Donald P. Green, and Ron Shachar. 2003. "Voting May Be Habit-Forming: Evidence from a Randomized Field Experiment.” American Journal of Political Science 47: 540-550.

Gerber, Alan S., Gregory A. Huber, David Doherty, and Conor M. Dowling. 2011a. "Is There a Secret Ballot? Ballot Secrecy Perceptions and Their Implications for Voting Behavior.” Typescript, Yale University.

Gerber, Alan S., Gregory A. Huber, David Doherty, and Conor M. Dowling. 2011b. "The Social Consequences of Voting and Choosing a Partisan Identity.” Typescript, Yale University.

Gerber, Alan S., Gregory A. Huber, David Doherty, Conor M. Dowling, Connor Raso, and Shang E. Ha. 2011. "Personality Traits and Participation in Political Processes.” Journal of Politics 73: 692706.

Green, Donald P., and Alan S. Gerber. 2008. Get Out the Vote! How to Increase Voter Turnout. $2^{\text {nd }}$ ed. Washington, DC: Brookings Institution Press.

Grose, Christian R., and Carrie A. Russell. 2008. "Avoiding the Vote: A Theory and Field Experiment of the Social Costs of Public Political Participation.” (December 3). Available at SSRN: http://ssrn.com/abstract=1310868.

Heckelman, Jac C. 1995. “The Effect of the Secret Ballot on Voter Turnout Rates.” Public Choice 82: 107-124.

Heckelman, Jac C. 2000. "Revisiting the Relationship between Secret Ballots and Turnout: A New Test of Two Legal-Institutional Theories.” American Politics Quarterly 28: 194-215.

Heckelman, Jac C. 2004. “The Secret Ballot Protects the Incumbency Advantage.” The Independent Review 8: 419-425. 
Heckelman, Jac C., and Andrew J. Yates. 2002. "Incumbency Preservation through Electoral Legislation: The Case of the Secret Ballot.” Economics of Governance 3: 47-57.

Jackman, Robert W. 1987. "Political Institutions and Voter Turnout in the Industrial Democracies." American Political Science Review 81: 405-423.

Kousser, Morgan. 1974. The Shaping of Southern Politics: Suffrage Restrictions and the Establishment of the One-Party South, 1880-1910. New Haven, CT: Yale University Press.

Mann, Christopher B. 2010. "Is there Backlash to Social Pressure? A Large-scale Field Experiment on Voter Mobilization.” Political Behavior 32: 387-408.

Milbrath, Lester W. and Madan Lal Goel. 1977. Political participation: How and Why Do People Get Involved in Politics? Chicago: Rand McNally College Pub. Co.

Panagopoulos, Costas. 2010. “Affect, Social Pressure and Prosocial Motivation: Field Experimental Evidence of the Mobilizing Effects of Pride, Shame and Publicizing Voting Behavior.” Political Behavior 32: 369-386.

Plutzer, Eric. 2002. "Becoming a Habitual Voter: Inertia, Resources, and Growth in Young Adulthood.” American Political Science Review 96: 41-56

Powell, G. Bingham, Jr. 1986. “American Voter Turnout in Comparative Perspective.” American Political Science Review 80: 17-43.

Rosenstone, Steven J., and John Mark Hansen. 1993. Mobilization, Participation, and Democracy in America. New York, NY: MacMillan.

Rusk, Jerrold G. 1970. “The Effect of the Australian Ballot Reform on Split Ticket Voting: 1876-1908.” American Political Science Review 64:1220-1238.

Schaffer, Frederic C. 1998. Democracy in Translation: Understanding Politics in an Unfamiliar Culture. Ithaca: Cornell University Press.

Slemrod, Joel, Marsha Blumenthal, and Charles Christian. 2001. "Taxpayer Response to an Increased Probability of Audit: Evidence from a Controlled Experiment in Minnesota.” Journal of Public Economics 79: 455-483.

Stokes, Susan C. 2005. "Perverse Accountability: A Formal Model of Machine Politics with Evidence from Argentina.” American Political Science Review 99: 315-325.

Timpone, Richard J. 1998. "Structure, Behavior, and Voter Turnout in the United States.” American Political Science Review 92: 145-158.

Wigmore, John H. 1889. The Australian Ballot System as Embodied in the Legislation of Various Countries. Boston, MA: C.C. Soule.

Wolfinger, Raymond E., and Steven J. Rosenstone. 1980. Who Votes?. New Haven, CT: Yale University Press. 


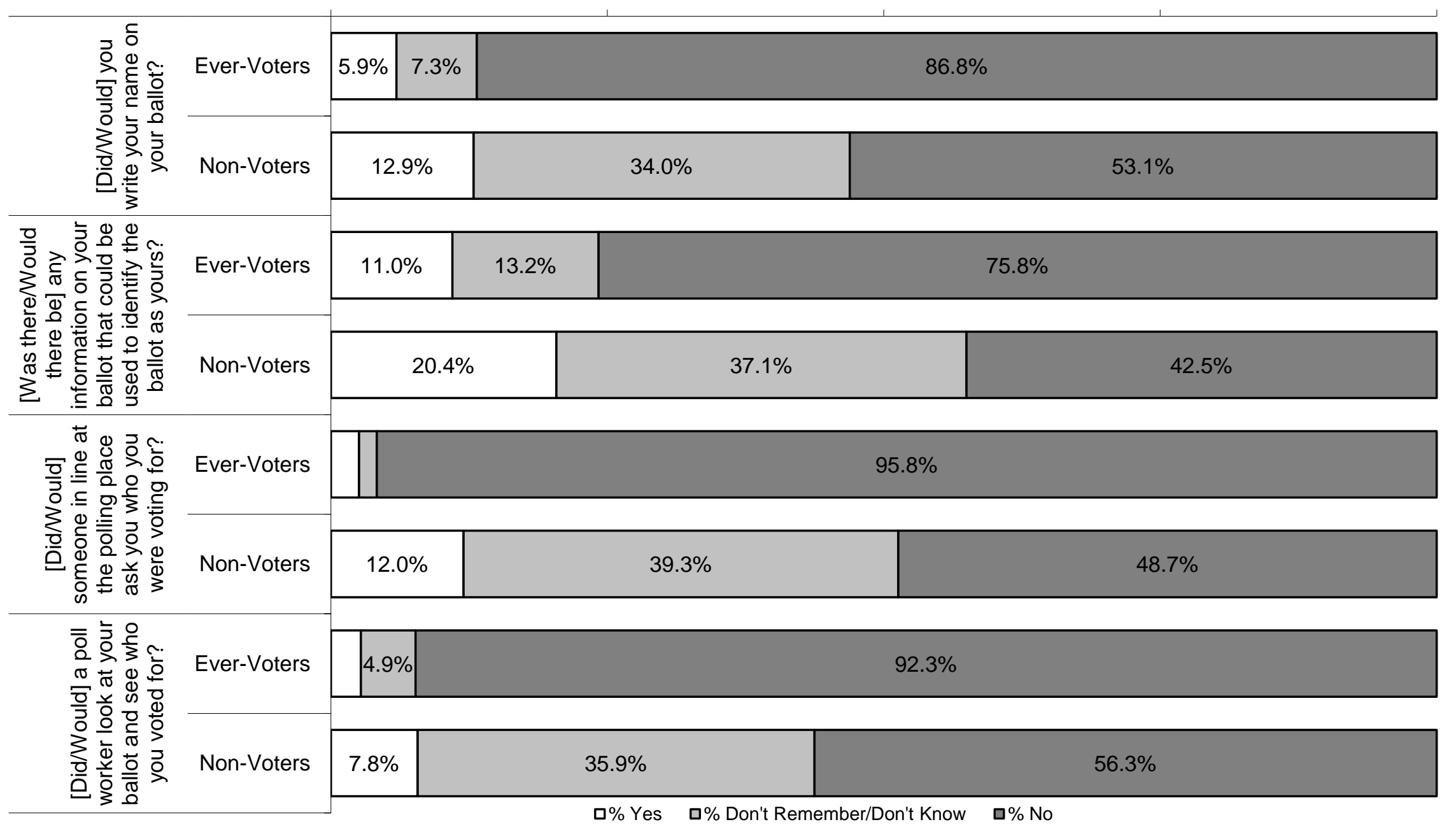

Source: 2010 Ballot Secrecy Survey. Cell entries are weighted percentages. Ever-Voters include those whose last reported vote was in person (early or on Election Day); $19 \%$ of survey respondents reported voting absentee, by mail, or could not recall how they last voted and are excluded from this analysis. Empty cells are $2.6 \%$ Yes and 1.6\% DR/DK for Ever-Voters to "...ask you who you were voting for?" and 2.7\% Yes for Ever-Voters to "...see who you voted for?". All differences in distributions of responses between Ever- and Non-voters are statistically significant at $p<.05$ (test-statistic calculated with a weighted multinomial logit regression predicting responses with an indicator for Non-voters, robust [Huber/White] standard errors). N ranges from 2418 to 2429. 


\section{Table 1: Field Experiment Design}

\begin{tabular}{|c|c|}
\hline Stage 1: Select Eligible Sample & $\begin{array}{l}\text { Randomly select a single registrant in every household from eligible active registrants in Connecticut Voter File (June, 2010). } \\
\text { Eligible registrants are those: } \\
\text { (1) age } 18-85 \text {, } \\
\text { (2) with a valid Connecticut mailing address (mailable and current per NCOA list, October 2010) that is not a PO Box, } \\
\text { (3) who had not voted absentee in } 2006,2008 \text {, or } 2010 \text {, and } \\
\text { (4) who are not from a household with more than } 5 \text { registrants at a single address. }\end{array}$ \\
\hline Stage 2: Identify Strata & $\begin{array}{l}\text { There are } 3 \text { Treatment Strata: } \\
\text { Recently registered non-voters: Those who registered after the November } 2004 \text { election and have never voted. } \\
\text { Longstanding registered non-voters: Those who registered on or before the November } 2004 \text { election and have never voted. } \\
\text { Ever-voters: All other registrants who have ever voted. }\end{array}$ \\
\hline Stage 3: Assign Treatments & $\begin{array}{l}\text { There are Seven Treatment Mailings and an untreated Control Group (Treatment assignment within each Stratum is detailed in Table 3): } \\
\text { Secrecy Treatments: (1) SOS Secrecy } 1 \text { (Anonymity), (2) SOS Secrecy } 2 \text { (No Intimidation), (3) SOS Secrecy Combined } \\
\text { Placebo Treatments: (4) SOS Short, (5) SOS Control } \\
\text { Civic Duty Treatments: (6) SOS Civic Duty, (7) Generic ("Connecticut Votes") Civic Duty }\end{array}$ \\
\hline Stage 4: Collect Post-Treatment Data & Code 2010 Participation from Connecticut Voter file; unmatched cases count as not voting. \\
\hline
\end{tabular}

Note: SOS=Secretary of State; NCOA=National Change of Address. 
Table 2a: Summary Statistics for Treatment Stratum by Intervention Assignment

(1)

(2)

(3)

(4)

(5)

(6)

(7)

(8)

(9)

Treatment:

Treatment: SOS Secrecy 2 Treatment: Treatment: Treatment:

SOS Secrecy 1 (No SOS Secrecy SOS Short SOS Control

Control Group (Anonymity) Intimidation) Combined

Treatment: Generic Civic

(Placebo) SOS Civic Duty

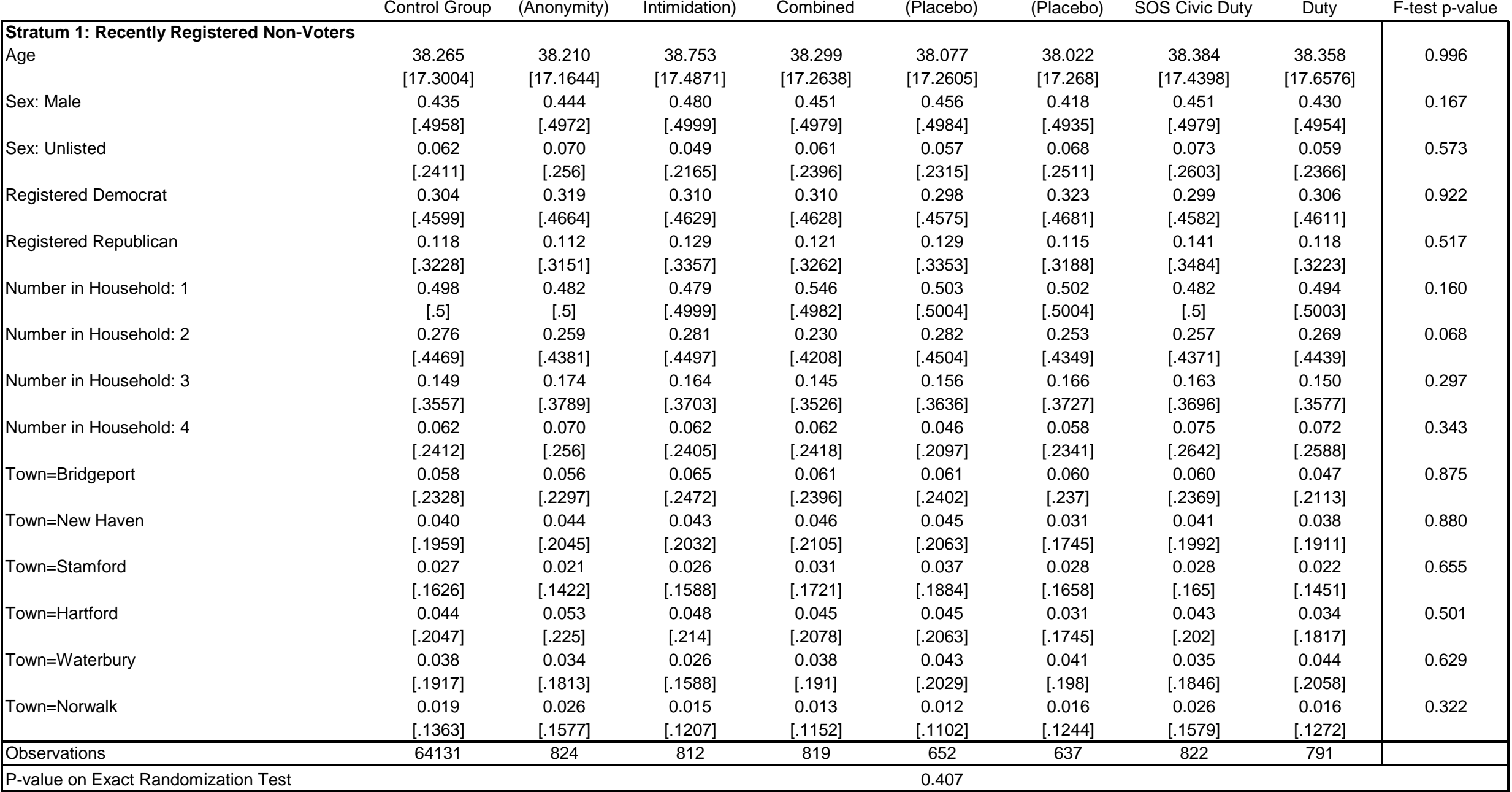

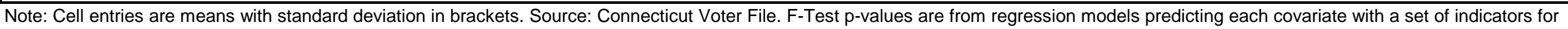
each intervention. See text for discussion of exact randomization test. 
Table 2b: Summary Statistics for Treatment Stratum by Intervention Assignment

(1)

(2)

(3)

(4)

(5)

(6)

(7)

(8)

(9)

Treatment:

Treatment: SOS Secrecy 2 Treatment:

SOS Secrecy 1 (No SOS Secrecy

Treatment: Treatment:

SOS Short SOS Control

Treatment:

Treatment: Generic Civic

Con

Stratum 2: Lo
Age
Sex: Male
Sex: Unlisted

Registered Democrat

Intimidation) Combined (Placebo) SOS Civic Duty

Duty

F-test p-value

\begin{tabular}{|c|c|c|c|c|c|c|c|c|}
\hline 48.254 & 48.689 & 46.830 & 48.377 & 47.333 & 47.505 & 48.539 & 48.777 & 0.952 \\
\hline [15.1182] & [15.708] & [15.2034] & {$[14.096]$} & [15.8961] & [14.8285] & [15.3997] & [16.2488] & \\
\hline 0.391 & 0.420 & 0.407 & 0.263 & 0.467 & 0.374 & 0.378 & 0.397 & 0.131 \\
\hline [.488] & [.4957] & [.4932] & [.4423] & {$[.5013]$} & [.4863] & [.4865] & [.4912] & \\
\hline 0.145 & 0.185 & 0.126 & 0.175 & 0.143 & 0.121 & 0.203 & 0.124 & 0.370 \\
\hline$[.3516]$ & [.3898] & [.333] & [.382] & [.3516] & [.328] & {$[.4035]$} & [.3309] & \\
\hline 0.311 & 0.286 & 0.326 & 0.360 & 0.295 & 0.253 & 0.329 & 0.306 & 0.816 \\
\hline [.463] & [.4537] & [.4705] & [.482] & [.4583] & [.4367] & [.4714] & [.4627] & \\
\hline 0.140 & 0.126 & 0.163 & 0.088 & 0.171 & 0.111 & 0.147 & 0.141 & 0.663 \\
\hline [.3471] & [.3333] & [.3707] & [.2841] & [.3787] & [.3159] & [.3552] & [.3489] & \\
\hline 0.497 & 0.555 & 0.496 & 0.579 & 0.410 & 0.485 & 0.532 & 0.488 & 0.282 \\
\hline$[.5]$ & [.4991] & [.5018] & [.4959] & [.4941] & [.5023] & [.5008] & [.5019] & \\
\hline 0.299 & 0.210 & 0.267 & 0.254 & 0.352 & 0.253 & 0.294 & 0.322 & 0.252 \\
\hline$[.4578]$ & [.4091] & [.4439] & {$[.4374]$} & {$[.48]$} & [.4367] & [.4571] & [.4693] & \\
\hline 0.137 & 0.168 & 0.119 & 0.105 & 0.200 & 0.212 & 0.119 & 0.141 & 0.139 \\
\hline [.3438] & [.3755] & [.3244] & [.3082] & [.4019] & [.4109] & [.3248] & [.3489] & \\
\hline 0.053 & 0.050 & 0.082 & 0.053 & 0.029 & 0.051 & 0.042 & 0.041 & 0.764 \\
\hline [.2239] & [.2197] & [.2746] & [.2243] & [.1674] & [.2201] & [.2012] & [.1999] & \\
\hline 0.068 & 0.059 & 0.096 & 0.079 & 0.076 & 0.020 & 0.091 & 0.074 & 0.425 \\
\hline$[.2516]$ & [.2363] & [.2961] & [.2708] & [.2666] & [.1414] & [.2885] & [.2635] & \\
\hline 0.050 & 0.076 & 0.067 & 0.070 & 0.048 & 0.040 & 0.063 & 0.050 & 0.771 \\
\hline [.218] & [.2655] & [.2504] & {$[.2566]$} & {$[.214]$} & [.1979] & [.2437] & [.218] & \\
\hline 0.034 & 0.025 & 0.030 & 0.044 & 0.010 & 0.010 & 0.028 & 0.041 & 0.701 \\
\hline [.181] & [.1574] & [.1702] & [.2057] & {$[.0976]$} & [.1005] & [.1655] & [.1999] & \\
\hline 0.039 & 0.034 & 0.030 & 0.026 & 0.048 & 0.051 & 0.070 & 0.033 & 0.625 \\
\hline [.1929] & [.181] & [.1702] & [.1608] & {$[.214]$} & [.2201] & [.2559] & [.1795] & \\
\hline 0.084 & 0.076 & 0.082 & 0.088 & 0.095 & 0.111 & 0.084 & 0.066 & 0.973 \\
\hline [.2779] & {$[.2655]$} & {$[.2746]$} & [.2841] & [.295] & [.3159] & [.2782] & [.2495] & \\
\hline 0.006 & 0.000 & 0.000 & 0.009 & 0.000 & 0.010 & 0.000 & 0.000 & 0.765 \\
\hline$[.0757]$ & & & {$[.0937]$} & & [.1005] & & & \\
\hline 68023 & 119 & 135 & 114 & 105 & 99 & 143 & 121 & \\
\hline
\end{tabular}

P-value on Exact Randomization Test

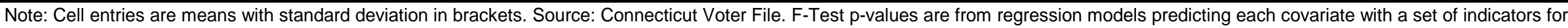
each intervention. See text for discussion of exact randomization test. 
Table 2c: Summary Statistics for Treatment Stratum by Intervention Assignment

(1)

(2)

(3)

(4)

(5)

(6)

(7)

(8)

(9)

Treatment:

Treatment: SOS Secrecy 2 Treatment: Treatment: Treatment:

$\begin{array}{lll}\text { SOS Secrecy } 1 & \text { (No SOS Secrecy }\end{array}$

SOS Short SOS Control

(Placebo) (Placebo)

Treatment:

\begin{tabular}{|c|c|c|c|c|c|c|c|c|c|}
\hline \multirow{2}{*}{\multicolumn{10}{|c|}{ Stratum 3: Ever Voters }} \\
\hline & & & & & & & & & \\
\hline Voted 2006 & $\begin{array}{c}0.523 \\
{[.4995]}\end{array}$ & $\begin{array}{c}0.529 \\
{[.4993]}\end{array}$ & $\begin{array}{c}0.526 \\
{[.4995]}\end{array}$ & $\begin{array}{c}0.523 \\
{[.4996]}\end{array}$ & $\begin{array}{c}0.521 \\
{[.4998]}\end{array}$ & $\begin{array}{c}0.532 \\
{[.4992]}\end{array}$ & $\begin{array}{c}0.528 \\
{[.4994]}\end{array}$ & $\begin{array}{c}0.532 \\
{[.4991]}\end{array}$ & 0.996 \\
\hline \multirow[t]{2}{*}{ Voted 2004} & 0.618 & 0.616 & 0.613 & 0.608 & 0.618 & 0.610 & 0.610 & 0.616 & 0.995 \\
\hline & {$[.4859]$} & {$[.4866]$} & {$[.4872]$} & {$[.4883]$} & {$[.4861]$} & {$[.4879]$} & {$[.4878]$} & {$[.4866]$} & \\
\hline \multirow[t]{2}{*}{ Voted 2008} & 0.888 & 0.890 & 0.885 & 0.885 & 0.888 & 0.895 & 0.895 & 0.889 & 0.981 \\
\hline & {$[.3154]$} & [.313] & {$[.3188]$} & {$[.3192]$} & {$[.3157]$} & {$[.3065]$} & {$[.3073]$} & {$[.3141]$} & \\
\hline \multirow[t]{2}{*}{ Age } & 52.158 & 51.979 & 51.892 & 52.173 & 52.445 & 51.986 & 51.694 & 51.504 & 0.761 \\
\hline & [15.7728] & [15.6388] & [15.5082] & {$[15.7735]$} & {$[15.6856]$} & {$[15.7316]$} & [15.6557] & [16.0351] & \\
\hline \multirow[t]{2}{*}{ Sex: Male } & 0.374 & 0.356 & 0.374 & 0.379 & 0.387 & 0.366 & 0.377 & 0.371 & 0.808 \\
\hline & {$[.4838]$} & {$[.4788]$} & {$[.4841]$} & {$[.4854]$} & {$[.4872]$} & {$[.4819]$} & {$[.4848]$} & {$[.4832]$} & \\
\hline \multirow[t]{2}{*}{ Sex: Unlisted } & 0.133 & 0.141 & 0.131 & 0.128 & 0.114 & 0.128 & 0.136 & 0.145 & 0.376 \\
\hline & {$[.34]$} & {$[.3478]$} & {$[.3378]$} & {$[.3345]$} & {$[.3176]$} & {$[.3343]$} & {$[.3433]$} & {$[.3519]$} & \\
\hline \multirow[t]{2}{*}{ Registered Democrat } & 0.381 & 0.380 & 0.418 & 0.386 & 0.382 & 0.362 & 0.365 & 0.370 & 0.060 \\
\hline & {$[.4858]$} & {$[.4856]$} & {$[.4933]$} & {$[.4869]$} & {$[.4861]$} & {$[.4807]$} & {$[.4815]$} & {$[.4829]$} & \\
\hline \multirow[t]{2}{*}{ Registered Republican } & 0.214 & 0.196 & 0.207 & 0.192 & 0.204 & 0.224 & 0.231 & 0.220 & 0.094 \\
\hline & {$[.4102]$} & {$[.3973]$} & {$[.4054]$} & {$[.3936]$} & {$[.4031]$} & {$[.4172]$} & {$[.4215]$} & {$[.4143]$} & \\
\hline \multirow[t]{2}{*}{ Number in Household: 1} & 0.369 & 0.380 & 0.372 & 0.355 & 0.381 & 0.356 & 0.359 & 0.351 & 0.499 \\
\hline & {$[.4826]$} & {$[.4855]$} & {$[.4834]$} & {$[.4785]$} & {$[.4859]$} & {$[.4789]$} & {$[.4798]$} & {$[.4775]$} & \\
\hline \multirow[t]{2}{*}{ Number in Household: 2} & 0.445 & 0.444 & 0.440 & 0.459 & 0.437 & 0.456 & 0.457 & 0.461 & 0.765 \\
\hline & {$[.497]$} & {$[.497]$} & {$[.4965]$} & {$[.4985]$} & {$[.4962]$} & {$[.4983]$} & {$[.4983]$} & {$[.4986]$} & \\
\hline \multirow[t]{2}{*}{ Number in Household: 3} & 0.128 & 0.120 & 0.139 & 0.124 & 0.122 & 0.128 & 0.125 & 0.123 & 0.824 \\
\hline & {$[.3346]$} & {$[.3253]$} & {$[.346]$} & {$[.3296]$} & {$[.3269]$} & {$[.3343]$} & {$[.3306]$} & {$[.3286]$} & \\
\hline \multirow[t]{2}{*}{ Number in Household: 4} & 0.046 & 0.048 & 0.041 & 0.051 & 0.051 & 0.050 & 0.050 & 0.055 & 0.689 \\
\hline & {$[.2097]$} & {$[.2137]$} & [.1993] & [.2192] & {$[.22]$} & {$[.2189]$} & {$[.217]$} & {$[.2289]$} & \\
\hline \multirow[t]{2}{*}{ Town=Bridgeport } & 0.031 & 0.031 & 0.032 & 0.033 & 0.031 & 0.029 & 0.030 & 0.033 & 0.999 \\
\hline & {$[.173]$} & {$[.1743]$} & {$[.1757]$} & {$[.1784]$} & {$[.1744]$} & {$[.1674]$} & {$[.1695]$} & {$[.1774]$} & \\
\hline \multirow[t]{2}{*}{ Town=New Haven } & 0.036 & 0.034 & 0.025 & 0.036 & 0.038 & 0.034 & 0.034 & 0.032 & 0.583 \\
\hline & {$[.1857]$} & {$[.181]$} & {$[.1557]$} & {$[.1864]$} & {$[.1904]$} & {$[.1803]$} & {$[.1815]$} & {$[.1757]$} & \\
\hline \multirow[t]{2}{*}{ Town=Stamford } & 0.032 & 0.033 & 0.034 & 0.036 & 0.034 & 0.032 & 0.035 & 0.031 & 0.989 \\
\hline & {$[.175]$} & {$[.1777]$} & {$[.1807]$} & {$[.1864]$} & {$[.1806]$} & {$[.1761]$} & {$[.1831]$} & {$[.174]$} & \\
\hline \multirow[t]{2}{*}{ Town=Hartford } & 0.025 & 0.020 & 0.029 & 0.022 & 0.028 & 0.022 & 0.020 & 0.023 & 0.598 \\
\hline & {$[.1563]$} & {$[.1394]$} & {$[.167]$} & {$[.1471]$} & {$[.1657]$} & {$[.1481]$} & {$[.1398]$} & {$[.1498]$} & \\
\hline \multirow[t]{2}{*}{ Town=Waterbury } & 0.026 & 0.029 & 0.029 & 0.026 & 0.028 & 0.030 & 0.023 & 0.028 & 0.931 \\
\hline & {$[.1589]$} & {$[.169]$} & {$[.1688]$} & {$[.1589]$} & {$[.1657]$} & {$[.1696]$} & {$[.1504]$} & {$[.1651]$} & \\
\hline \multirow[t]{2}{*}{ Town=Norwalk } & 0.028 & 0.021 & 0.024 & 0.027 & 0.030 & 0.023 & 0.024 & 0.026 & 0.764 \\
\hline & {$[.1642]$} & {$[.1438]$} & {$[.1518]$} & {$[.1627]$} & {$[.1701]$} & {$[.1507]$} & {$[.1545]$} & {$[.1577]$} & \\
\hline Observations & 8223 & 1564 & 1569 & 1582 & 1275 & 1249 & 1555 & 1569 & \\
\hline P-value on Exact Randomization Test & & & & & 0.309 & & & & \\
\hline
\end{tabular}

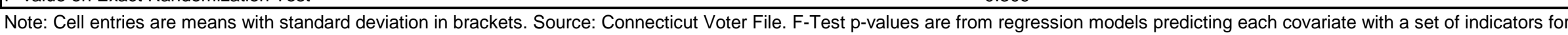
each intervention. See text for discussion of exact randomization test. 
Table 3: Counts of Control and Treatment Assignment by Stratum

\begin{tabular}{|l|ccc|}
\cline { 2 - 4 } \multicolumn{1}{c|}{} & \multicolumn{3}{c|}{ Stratum } \\
\cline { 2 - 4 } \multicolumn{1}{c|}{} & $\begin{array}{c}\text { Recently } \\
\text { Registered } \\
\text { Assignment }\end{array}$ & $\begin{array}{c}\text { Longstanding } \\
\text { Registered } \\
\text { Non-Voters }\end{array}$ & Ever-Voters \\
\hline Control Group & 64131 & 68023 & 8223 \\
Treatment: SOS Secrecy 1 (Anonymity) & 824 & 119 & 1564 \\
Treatment: SOS Secrecy 2 (No Intimidation) & 812 & 135 & 1569 \\
Treatment: SOS Secrecy Combined & 819 & 114 & 1582 \\
Treatment: SOS Short (Placebo) & 652 & 105 & 1275 \\
Treatment: SOS Control (Placebo) & 637 & 99 & 1249 \\
Treatment: SOS Civic Duty & 822 & 143 & 1555 \\
Treatment: Generic Civic Duty & 791 & 121 & 1569 \\
\hline
\end{tabular}

Note: Cell entries are counts of registrants assigned to that condition in that stratum. 
Starting Sample $[2,369,593]$

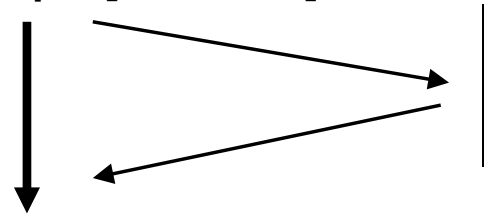

Active registrants, Age less than 86 and more than 17,

CT mailing address, Less than six at address, Not PO Box,

Not absentee voter

Population Filters $[1,527,658]$

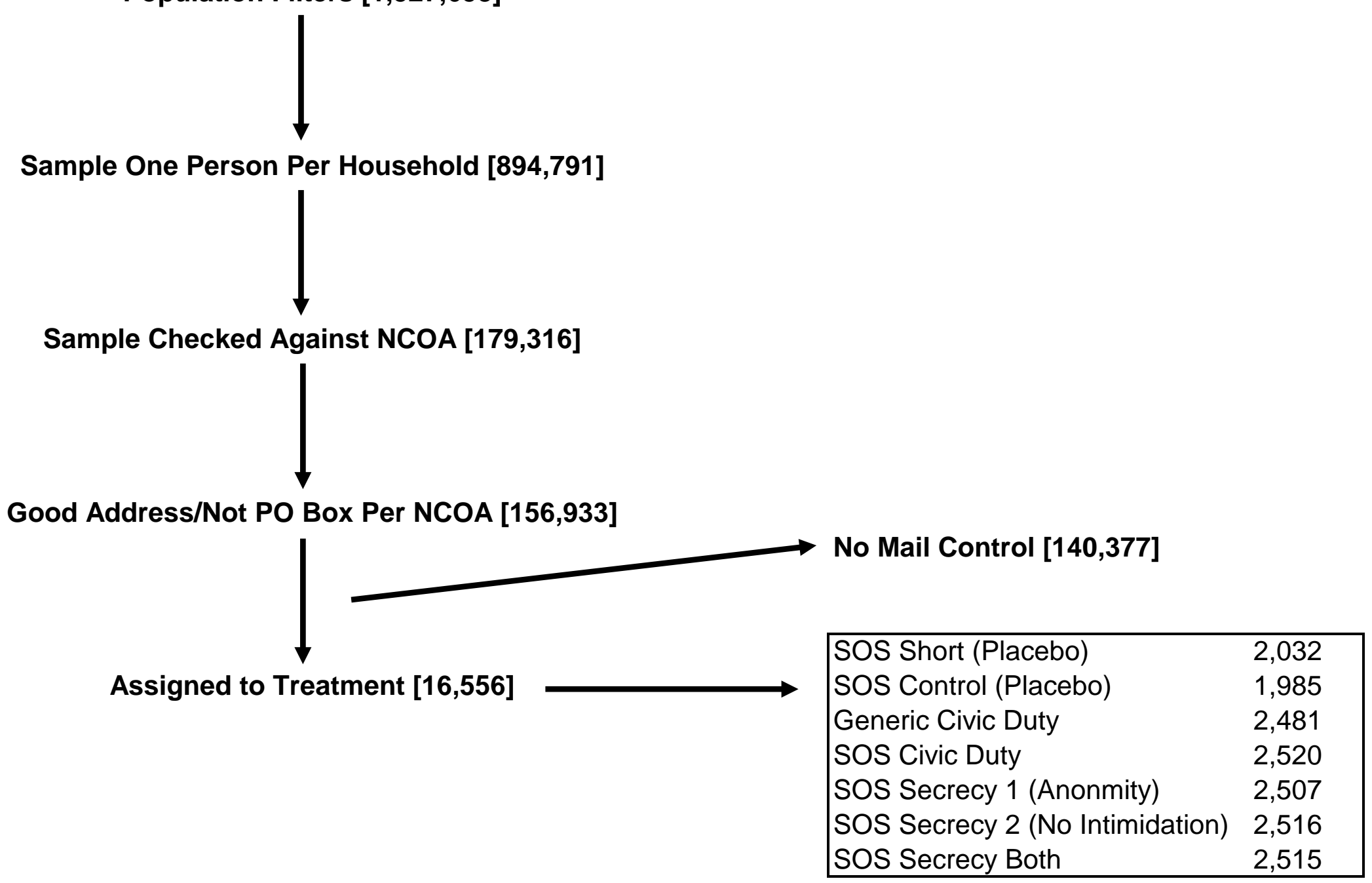


Table 4: 2010 Turnout Percentage by Control and Treatment Assignment by Stratum

\begin{tabular}{|c|c|c|c|}
\hline \multirow[b]{2}{*}{ Assignment } & \multicolumn{3}{|c|}{ Stratum } \\
\hline & $\begin{array}{c}\text { Recently } \\
\text { Registered } \\
\text { Non-Voters }\end{array}$ & $\begin{array}{l}\text { Longstanding } \\
\text { Registered } \\
\text { Non-Voters }\end{array}$ & Ever-Voters \\
\hline Control Group & $\begin{array}{c}17.0 \% \\
(0.1)\end{array}$ & $\begin{array}{c}13.2 \% \\
(0.1)\end{array}$ & $\begin{array}{c}62.6 \% \\
(0.5)\end{array}$ \\
\hline Treatment: SOS Secrecy 1 (Anonymity) & $\begin{array}{l}19.8 \\
(1.4)\end{array}$ & $\begin{array}{l}13.4 \\
(3.1)\end{array}$ & $\begin{array}{l}62.7 \\
(1.2)\end{array}$ \\
\hline Treatment: SOS Secrecy 2 (No Intimidation) & $\begin{array}{l}21.1 \\
(1.4)\end{array}$ & $\begin{array}{l}14.8 \\
(3.1)\end{array}$ & $\begin{array}{l}63.8 \\
(1.2)\end{array}$ \\
\hline Treatment: SOS Secrecy Combined & $\begin{array}{l}20.5 \\
(1.4)\end{array}$ & $\begin{array}{l}17.5 \\
(3.6)\end{array}$ & $\begin{array}{l}63.7 \\
(1.2)\end{array}$ \\
\hline Treatment: SOS Short (Placebo) & $\begin{array}{l}16.3 \\
(1.4)\end{array}$ & $\begin{array}{l}14.3 \\
(3.4)\end{array}$ & $\begin{array}{l}64.9 \\
(1.3)\end{array}$ \\
\hline Treatment: SOS Control (Placebo) & $\begin{array}{l}16.8 \\
(1.5)\end{array}$ & $\begin{array}{c}10.1 \\
(3)\end{array}$ & $\begin{array}{l}65.0 \\
(1.4)\end{array}$ \\
\hline $\begin{array}{l}\text { Treatment: SOS Civic Duty } \\
\text { Treatment: Generic Civic Duty }\end{array}$ & $\begin{array}{l}18.2 \\
(1.3) \\
17.6 \\
(1.4)\end{array}$ & $\begin{array}{l}11.2 \\
(2.6) \\
10.7 \\
(2.8)\end{array}$ & $\begin{array}{l}62.1 \\
(1.2) \\
64.2 \\
(1.2)\end{array}$ \\
\hline
\end{tabular}

Note: Cell entries are percentage voting as recorded in CT Voter File, standard errors in parentheses calculated from test of sample proportion. Registrants not matched to postelection file counted as non-voters. 
Table 5: OLS Regressions Predicting 2010 Turnout by Stratum

\begin{tabular}{|c|c|c|c|c|c|c|c|c|c|c|c|c|}
\hline & (1) & (2) & (3) & (4) & (5) & (6) & $(7)$ & $(8)$ & (9) & $(10)$ & \multicolumn{2}{|l|}{$(11)$} \\
\hline Stratum: & \multicolumn{2}{|c|}{$\begin{array}{l}\text { Recently Registered Non- } \\
\text { Voters }\end{array}$} & \multicolumn{2}{|c|}{$\begin{array}{l}\text { Longstanding Registered } \\
\text { Non-Voters }\end{array}$} & \multicolumn{2}{|c|}{ Ever Voters } & \multicolumn{2}{|c|}{$\begin{array}{c}\text { Recently Registered Non- } \\
\text { Voters, Pooled Secrecy } \\
\text { vs. Placebo }\end{array}$} & \multicolumn{2}{|c|}{$\begin{array}{l}\text { Longstanding Registered } \\
\text { Non-Voters, Pooled } \\
\text { Secrecy vs. Placebo }\end{array}$} & \multicolumn{2}{|c|}{$\begin{array}{l}\text { Ever Voters, Pooled } \\
\text { Secrecy vs. Placebo }\end{array}$} \\
\hline Included Assignments & \multicolumn{6}{|c|}{ All Assignments and Control } & \multicolumn{6}{|c|}{$\begin{array}{l}\text { Restricted to those assigned to Placebo (SOS Short and SOS Control) } \\
\text { or Any Secrecy (SOS Secrecy 1, SOS Secrecy 2, SOS Secrecy Combined) }\end{array}$} \\
\hline Comparisons: & \multicolumn{6}{|c|}{ To Control (Omitted Category) } & \multicolumn{6}{|c|}{ To Placebo Treatments (Omitted Category) } \\
\hline Treatment: SOS Secrecy 1 (Anonymity) & $\begin{array}{c}0.028 \\
{[0.014]^{\star *}}\end{array}$ & $\begin{array}{c}0.028 \\
{[0.014]^{\star \star}}\end{array}$ & $\begin{array}{c}0.002 \\
{[0.031]}\end{array}$ & $\begin{array}{c}0.013 \\
{[0.030]}\end{array}$ & $\begin{array}{c}0.001 \\
{[0.013]}\end{array}$ & $\begin{array}{c}0.002 \\
{[0.012]}\end{array}$ & & & & & & \\
\hline Treatment: Sos Secrecy 2 (No Intimidation) & $\begin{array}{c}0.040 \\
{[0.014]^{\star * *}}\end{array}$ & $\begin{array}{c}0.035 \\
{[0.014]^{\star \star}}\end{array}$ & $\begin{array}{l}0.016 \\
{[0.031]}\end{array}$ & $\begin{array}{c}0.023 \\
{[0.028]}\end{array}$ & $\begin{array}{c}0.012 \\
{[0.013]}\end{array}$ & $\begin{array}{c}0.010 \\
{[0.012]}\end{array}$ & & & & & & \\
\hline Treatment: SOS Secrecy Combined & $\begin{array}{c}0.035 \\
{[0.014]^{\star *}}\end{array}$ & $\begin{array}{c}0.038 \\
{[0.014]^{\star * *}}\end{array}$ & $\begin{array}{l}0.043 \\
{[0.036]}\end{array}$ & $\begin{array}{c}0.057 \\
{[0.034]^{*}}\end{array}$ & $\begin{array}{c}0.011 \\
{[0.013]}\end{array}$ & $\begin{array}{l}0.013 \\
{[0.012]}\end{array}$ & & & & & & \\
\hline Any Secrecy Treatment & & & & & & & $\begin{array}{c}0.039 \\
{[0.013]^{\star \star \star}}\end{array}$ & $\begin{array}{c}0.038 \\
{[0.013]^{\star \star \star}}\end{array}$ & $\begin{array}{c}0.030 \\
{[0.030]}\end{array}$ & $\begin{array}{c}0.044 \\
{[0.029]}\end{array}$ & $\begin{array}{l}-0.016 \\
{[0.012]}\end{array}$ & $\begin{array}{l}-0.014 \\
{[0.011]}\end{array}$ \\
\hline Treatment: SOS Short (Placebo) & $\begin{array}{l}-0.008 \\
{[0.015]}\end{array}$ & $\begin{array}{l}-0.008 \\
{[0.014]}\end{array}$ & $\begin{array}{c}0.011 \\
{[0.034]}\end{array}$ & $\begin{array}{c}0.009 \\
{[0.031]}\end{array}$ & $\begin{array}{c}0.024 \\
{[0.014]^{*}}\end{array}$ & $\begin{array}{c}0.025 \\
{[0.013]^{\star}}\end{array}$ & & & & & & \\
\hline Treatment: SOS Control (Placebo) & $\begin{array}{l}-0.002 \\
{[0.015]}\end{array}$ & $\begin{array}{l}-0.001 \\
{[0.015]}\end{array}$ & $\begin{array}{l}-0.031 \\
{[0.030]}\end{array}$ & $\begin{array}{l}-0.028 \\
{[0.029]}\end{array}$ & $\begin{array}{c}0.024 \\
{[0.015]^{*}}\end{array}$ & $\begin{array}{c}0.020 \\
{[0.013]}\end{array}$ & & & & & & \\
\hline Treatment: SOS Civic Duty & $\begin{array}{c}0.012 \\
{[0.014]}\end{array}$ & $\begin{array}{c}0.010 \\
{[0.013]}\end{array}$ & $\begin{array}{l}-0.020 \\
{[0.026]}\end{array}$ & $\begin{array}{l}-0.006 \\
{[0.025]}\end{array}$ & $\begin{array}{l}-0.004 \\
{[0.013]}\end{array}$ & $\begin{array}{l}-0.009 \\
{[0.012]}\end{array}$ & & & & & & \\
\hline Treatment: Generic Civic Duty & $\begin{array}{c}0.005 \\
{[0.014]}\end{array}$ & $\begin{array}{c}0.005 \\
{[0.013]}\end{array}$ & $\begin{array}{l}-0.025 \\
{[0.028]}\end{array}$ & $\begin{array}{l}-0.031 \\
{[0.029]}\end{array}$ & $\begin{array}{c}0.016 \\
{[0.013]}\end{array}$ & $\begin{array}{c}0.016 \\
{[0.012]}\end{array}$ & & & & & & \\
\hline Constant & $\begin{array}{c}0.170 \\
{[0.001]^{\star \star *}}\end{array}$ & $\begin{array}{c}0.185 \\
{[0.011]^{\star * \star}}\end{array}$ & $\begin{array}{c}0.132 \\
{[0.001]^{\star * \star}}\end{array}$ & $\begin{array}{c}0.132 \\
{[0.010]^{\star * *}}\end{array}$ & $\begin{array}{c}0.626 \\
{[0.005]^{\star \star *}}\end{array}$ & $\begin{array}{c}0.154 \\
{[0.036]^{\star \star *}}\end{array}$ & $\begin{array}{c}0.165 \\
{[0.010]^{\star \star \star}}\end{array}$ & $\begin{array}{c}0.281 \\
{[0.058]^{\star \star \star}}\end{array}$ & $\begin{array}{c}0.123 \\
{[0.023]^{\star \star \star}}\end{array}$ & $\begin{array}{c}-0.019 \\
{[0.050]} \\
\end{array}$ & $\begin{array}{c}0.650 \\
{[0.009]^{\star \star \star}}\end{array}$ & $\begin{array}{c}0.277 \\
{[0.060]^{\star * \star}}\end{array}$ \\
\hline Observations & 69488 & 69488 & 68859 & 68859 & 18586 & 18586 & 3744 & 3744 & 572 & 572 & 7239 & 7239 \\
\hline R-squared & 0.000 & 0.046 & 0.000 & 0.099 & 0.000 & 0.191 & 0.002 & 0.052 & 0.002 & 0.137 & 0.000 & 0.178 \\
\hline F-Test p-value on joint significance of three Secrecy Treatments & 0.001 & 0.001 & 0.621 & 0.304 & 0.700 & 0.657 & 0.003 & 0.003 & 0.319 & 0.122 & 0.180 & 0.187 \\
\hline F-Test $p$-value on joint significance of two SOS Placebos & 0.858 & 0.845 & 0.564 & 0.590 & 0.087 & 0.070 & $\mathrm{n} / \mathrm{a}$ & $\mathrm{n} / \mathrm{a}$ & $\mathrm{n} / \mathrm{a}$ & $\mathrm{n} / \mathrm{a}$ & $\mathrm{n} / \mathrm{a}$ & $\mathrm{n} / \mathrm{a}$ \\
\hline Covariates included? & No & Yes & No & Yes & No & Yes & No & Yes & No & Yes & No & Yes \\
\hline
\end{tabular}

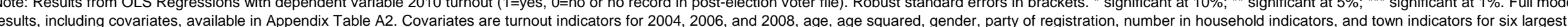
Connecticut towns (Bridgeport, New Haven, Stamford, Hartford, Waterbury, and Norwalk). 
Table A1: Summary Statistics for Each Stratum

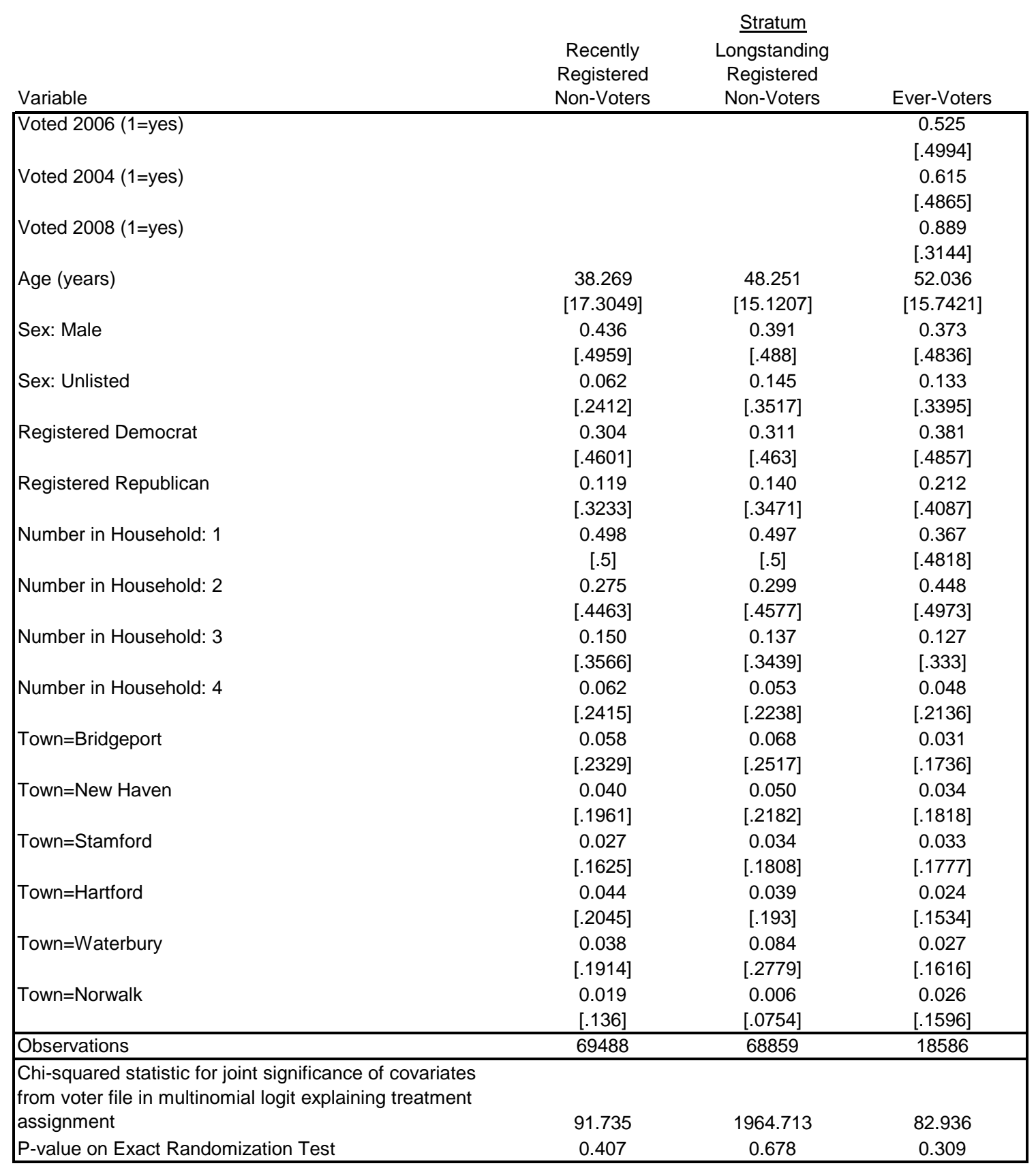

Note: Cell entries are means with standard deviation in brackets. Source: Connecticut Voter File. See text for discussion of exact randomization test. 
Figure A1: Tests of Randomization

Observed (Vertical line) and Counterfactual (Densities) Chi-Squared Statistics

Recently Registered Non-voters

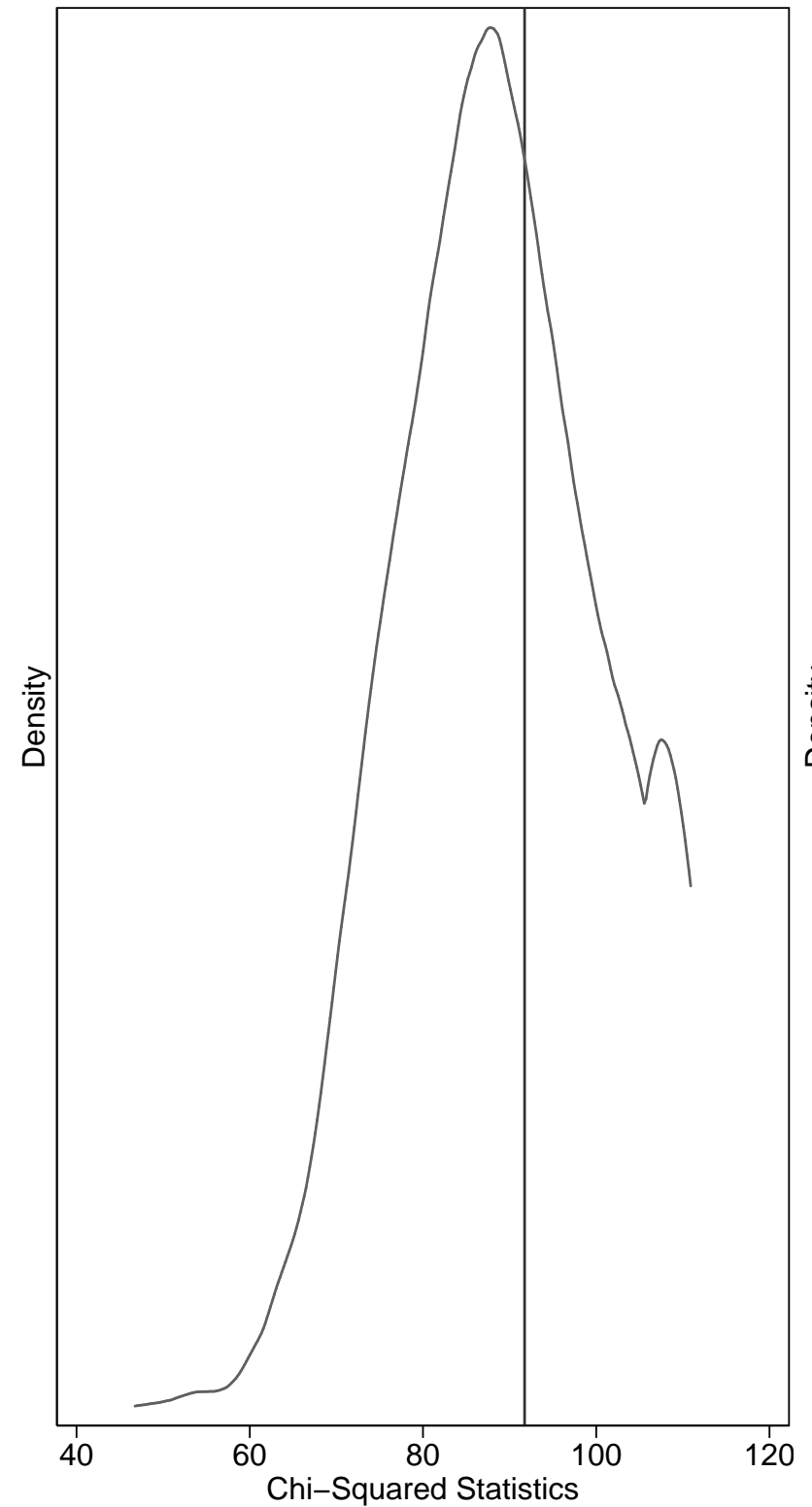

Longstanding Non-voters

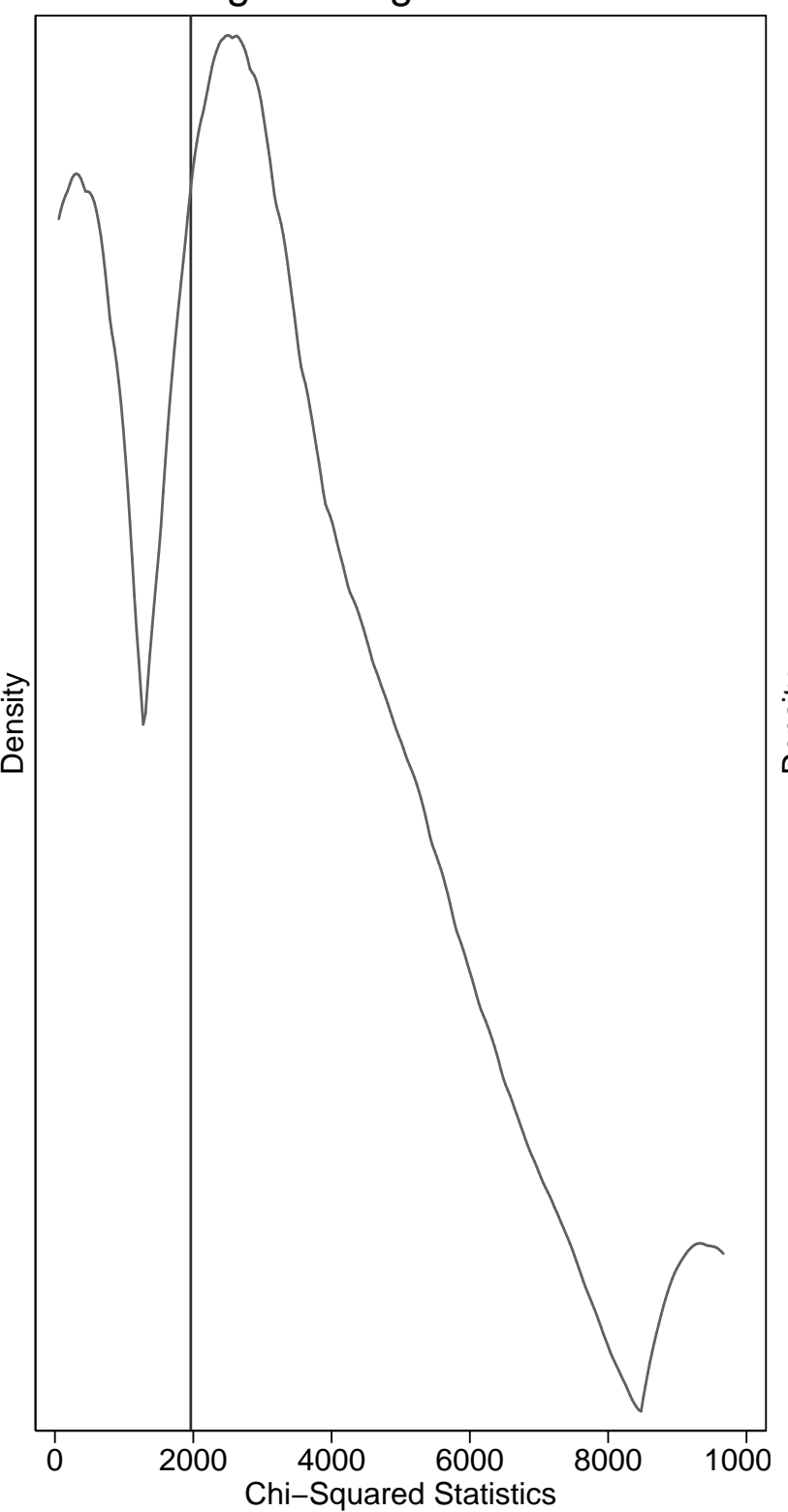

Ever-Voters

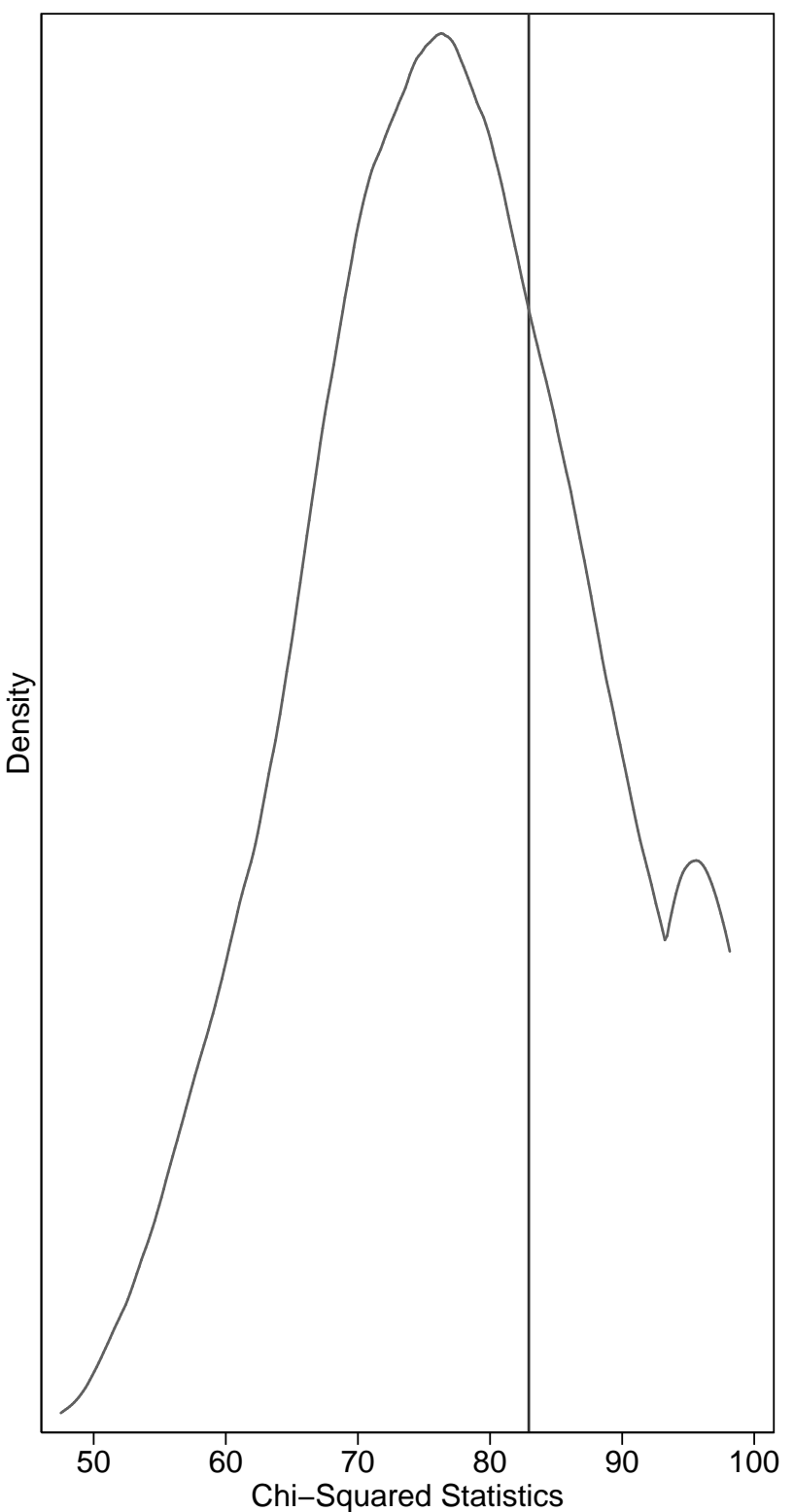

Densities are from 2000 independent alternative randomizations, top-coded at 95th percentile for graphing purposes. Beginning at left, empirical p-values in each cell are $0.407,0.678$, and 0.309 . 
Table A2: OLS Regressions Predicting 2010 Turnout by Stratum; Full Model Results

\begin{tabular}{|c|c|c|c|c|c|c|c|c|c|c|c|c|}
\hline & \multicolumn{2}{|r|}{ (2) } & \multicolumn{2}{|l|}{ (3) } & \multirow{2}{*}{\multicolumn{2}{|c|}{ Ever Voters }} & \multirow{2}{*}{\multicolumn{2}{|c|}{$\begin{array}{l}\text { Recently Registered Non- } \\
\text { Voter, Pooled Secrecy vs. } \\
\text { Placebo }\end{array}$}} & (9) & (10) & (11) & (12) \\
\hline Stratum: & $\begin{array}{r}\text { Recently Reg } \\
\text { Vo }\end{array}$ & jistered Non- & $\begin{array}{r}\text { Longstandi } \\
\text { Non }\end{array}$ & $\begin{array}{l}\text { Registered } \\
\text { loters }\end{array}$ & & & & & \multicolumn{2}{|c|}{$\begin{array}{l}\text { Longstanding Registered } \\
\text { Non-Voters, Pooled } \\
\text { Secrecy vs. Placebo }\end{array}$} & \multicolumn{2}{|c|}{$\begin{array}{l}\text { Ever Voters, Pooled } \\
\text { Secrecy vs. Placebo }\end{array}$} \\
\hline Included Assignments & \multicolumn{6}{|c|}{ All Assignments and Control } & \multicolumn{6}{|c|}{$\begin{array}{l}\text { Restricted to those assigned to Placebo (SOS Short and SOS Control) } \\
\text { or Any Secrecy (SOS Secrecy 1, SOS Secrecy 2, SOS Secrecy Combined) }\end{array}$} \\
\hline Comparisons: & \multicolumn{6}{|c|}{ To Control (Omitted Category) } & \multicolumn{6}{|c|}{ To Placebo Treatments (Omitted Category) } \\
\hline Treatment: SOS Secrecy 1 (Anonymity) & 0.028 & 0.028 & 0.002 & 0.013 & 0.001 & 0.002 & & & & & & \\
\hline & {$[0.014]^{\star \star}$} & {$[0.014]^{\star \star}$} & {$[0.031]$} & {$[0.030]$} & [0.013] & {$[0.012]$} & & & & & & \\
\hline Treatment: SOS Secrecy 2 (No Intimidation) & 0.040 & 0.035 & 0.016 & 0.023 & 0.012 & 0.010 & & & & & & \\
\hline & {$[0.014]^{\star \star \star}$} & {$[0.014]^{\star \star}$} & {$[0.031]$} & [0.028] & {$[0.013]$} & {$[0.012]$} & & & & & & \\
\hline Treatment: SOS Secrecy Combined & $\begin{array}{c}0.035 \\
{[0.014]^{\star \star}}\end{array}$ & $\begin{array}{c}0.038 \\
{[0.014]^{* * *}}\end{array}$ & $\begin{array}{c}0.043 \\
{[0.036]}\end{array}$ & $\begin{array}{c}0.057 \\
{[0.034]^{\star}}\end{array}$ & $\begin{array}{c}0.011 \\
{[0.013]}\end{array}$ & $\begin{array}{r}0.013 \\
10.0121\end{array}$ & & & & & & \\
\hline Any Secrecy Treatment & & & & & & & $\begin{array}{c}0.039 \\
{[0.013]^{* * *}}\end{array}$ & $\begin{array}{c}0.038 \\
{[0.013]^{* * *}}\end{array}$ & $\begin{array}{c}0.030 \\
{[0.030]}\end{array}$ & $\begin{array}{c}0.044 \\
{[0.029]}\end{array}$ & $\begin{array}{l}-0.016 \\
{[0.012]}\end{array}$ & $\begin{array}{l}-0.014 \\
{[0.011]}\end{array}$ \\
\hline Treatment: SOS Short (Placebo) & $\begin{array}{l}-0.008 \\
{[0.015]}\end{array}$ & $\begin{array}{l}-0.008 \\
{[0.014]}\end{array}$ & $\begin{array}{c}0.011 \\
{[0.034]}\end{array}$ & $\begin{array}{c}0.009 \\
{[0.031]}\end{array}$ & $\begin{array}{c}0.024 \\
{[0.014]^{\star}}\end{array}$ & $\begin{array}{c}0.025 \\
{[0.013]^{*}}\end{array}$ & & & & & & \\
\hline Treatment: SOS Control (Placebo) & $\begin{array}{r}-0.002 \\
-0.015\end{array}$ & $\begin{array}{l}-0.001 \\
-0.015\end{array}$ & -0.031 & $\begin{array}{r}-0.028 \\
-0.0291\end{array}$ & 0.024 & 0.020 & & & & & & \\
\hline Treatment: SOS Civic Duty & 0.012 & 0.010 & -0.020 & -0.006 & -0.004 & -0.009 & & & & & & \\
\hline Treatment: Generic Civic Duty & $\begin{array}{c}{[0.014]} \\
0.005\end{array}$ & $\begin{array}{c}{[0.013]} \\
0.005\end{array}$ & $\begin{array}{l}{[0.026]} \\
-0.025\end{array}$ & $\begin{array}{l}{[0.025]} \\
-0.031\end{array}$ & $\begin{array}{c}{[0.013]} \\
0.016\end{array}$ & $\begin{array}{c}{[0.012]} \\
0.016\end{array}$ & & & & & & \\
\hline & [0.014] & {$[0.013]$} & {$[0.028]$} & [0.029] & {$[0.013]$} & {$[0.012]$} & & & & & & \\
\hline Voted 2006 & & & & & & $\begin{array}{c}0.227 \\
{[0.008]^{\star \star \star}}\end{array}$ & & & & & & {$[0.213]^{\star * *}$} \\
\hline Voted 2004 & & & & & & $\begin{array}{r}0.009 \\
0.0081\end{array}$ & & & & & & $\begin{array}{r}0.008 \\
{[0.0121}\end{array}$ \\
\hline Voted 2008 & & & & & & 0.241 & & & & & & 0.244 \\
\hline & & & & & & {$[0.011]^{\star \star \star}$} & & & & & & {$[0.017]^{\star \star \star}$} \\
\hline Age (mean-deviated) & & $\begin{array}{c}0.009 \\
{[0.000]^{* * *}}\end{array}$ & & $\begin{array}{c}0.009 \\
{[0.001]^{* * *}}\end{array}$ & & $\begin{array}{c}0.020 \\
{[0.001]^{* *}}\end{array}$ & & $\begin{array}{c}0.010 \\
{[0.002]^{* * *}}\end{array}$ & & $\begin{array}{c}0.006 \\
{[0.006]}\end{array}$ & & $\begin{array}{c}0.019 \\
{[0.002]^{* *}}\end{array}$ \\
\hline Age-Squared (in hundreds, mean-deviated) & & $\begin{array}{l}-0.007 \\
{[0.000]^{* \star *}}\end{array}$ & & $\begin{array}{c}-0.005 \\
0.0011^{* * *}\end{array}$ & & $\begin{array}{l}-0.015 \\
{[0.001]^{\star \star \star}}\end{array}$ & & $\begin{array}{c}-0.008 \\
{\left[0.0022^{* * *}\right.}\end{array}$ & & $\begin{array}{l}-0.002 \\
-0.006\end{array}$ & & $\begin{array}{l}-0.014 \\
{\left[0.0022^{* \star}\right.}\end{array}$ \\
\hline Sex: Male & & 0.003 & & $\begin{array}{r}-0.001 \\
-0.033\end{array}$ & & 0.025 & & 0.014 & & $\begin{array}{l}-0.043 \\
-0.0321\end{array}$ & & 0.028 \\
\hline & & {$[0.003]$} & & {$[0.003]$} & & {$[0.007]^{* \star *}$} & & {$[0.013]$} & & {$[0.032]$} & & {$[0.011]^{\star *}$} \\
\hline Sex: Unlisted & & -0.090 & & -0.111 & & 0.022 & & -0.146 & & -0.175 & & 0.017 \\
\hline Registered Democrat & & $\begin{array}{c}{[0.006]^{* * *}} \\
0.049\end{array}$ & & {$\left[\begin{array}{c}{[0.003]^{* \star * \star}} \\
0.019\end{array}\right.$} & & $\begin{array}{c}{[0.010]^{\star *}} \\
0.077\end{array}$ & & {$\left[\begin{array}{c}{[0.024]^{\text {t** }}} \\
0.021\end{array}\right.$} & & $\begin{array}{c}{\left[0.0377^{\star * *}\right.} \\
0.053\end{array}$ & & $\begin{array}{c}{[0.017]} \\
0.080\end{array}$ \\
\hline & & {$[0.003]^{* * *}$} & & {$[0.003]^{* * *}$} & & {$[0.008]^{* * *}$} & & {$[0.014]$} & & $\begin{array}{c}0.053 \\
{[0.032]^{*}}\end{array}$ & & $\begin{array}{c}0.080 \\
{[0.012]^{* \star *}}\end{array}$ \\
\hline Registered Republican & & 0.147 & & 0.096 & & 0.130 & & 0.141 & & 0.195 & & 0.138 \\
\hline & & {$[0.005]^{\star \star \star}$} & & {$[0.004]^{* \star *}$} & & {$[0.009]^{\star \star \star}$} & & {$[0.023]^{* \star \star}$} & & {$[0.055]^{\star \star \star}$} & & {$[0.014]^{\star \star *}$} \\
\hline Number in Household: 1 & & -0.040 & & -0.023 & & -0.030 & & -0.135 & & 0.123 & & -0.123 \\
\hline & & {$[0.011]^{\star \star \star}$} & & {$[0.009]^{\star \star}$} & & {$[0.034]$} & & {$[0.057]^{\star \star}$} & & {$[0.045]^{\star \star \star}$} & & {$[0.057]^{* *}$} \\
\hline Number in Household: 2 & & 0.027 & & 0.064 & & 0.048 & & -0.059 & & 0.187 & & -0.044 \\
\hline & & {$[0.011]^{\star \star}$} & & {$[0.010]^{\star \star \star}$} & & {$[0.034]$} & & [0.058] & & {$[0.051]^{\star \star \star}$} & & {$[0.057]$} \\
\hline Number in Household: 3 & & -0.002 & & 0.013 & & 0.005 & & -0.105 & & 0.211 & & -0.089 \\
\hline & & {$[0.011]$} & & {$[0.010]$} & & {$[0.035]$} & & {$[0.058]^{*}$} & & {$[0.054]^{\star \star \star}$} & & {$[0.058]$} \\
\hline Number in Household: 4 & & -0.003 & & 0.015 & & 0.038 & & -0.045 & & 0.172 & & -0.069 \\
\hline & & {$[0.012]$} & & {$[0.011]$} & & {$[0.036]$} & & {$[0.063]$} & & {$[0.072]^{\star *}$} & & {$[0.060]$} \\
\hline Town=Bridgeport & & -0.097 & & -0.143 & & -0.063 & & -0.096 & & -0.144 & & -0.080 \\
\hline & & {$[0.005]^{* * *}$} & & {$[0.003]^{\star \star \star}$} & & {$[0.019]^{\star \star \star}$} & & {$[0.022]^{* * *}$} & & {$[0.037]^{\star \star \star}$} & & {$[0.031]^{\star *}$} \\
\hline Town=New Haven & & $\begin{array}{l}-0.057 \\
{[0.006]^{* \star *}}\end{array}$ & & -0.103 & & -0.038 & & -0.062 & & -0.093 & & -0.034 \\
\hline Town=Stamford & & $\begin{array}{c}{[0.006]^{\star \star *}} \\
0.030\end{array}$ & & {$[0.003]^{* * *}$} & & $\begin{array}{c}{[0.017]^{\star *}} \\
0.173\end{array}$ & & & & {$[0.044]^{\star *}$} & & {$[0.028]$} \\
\hline & & $\begin{array}{c}0.030 \\
{[0.009]^{* * *}}\end{array}$ & & $\begin{array}{l}-0.034 \\
{\left[0.0077^{* * *}\right.}\end{array}$ & & $\begin{array}{l}0.173 \\
0.0199^{\star * \star}\end{array}$ & & $\begin{array}{l}0.024 \\
{[0.040]}\end{array}$ & & $\begin{array}{l}-0.096 \\
{[0.0801}\end{array}$ & & $\begin{array}{l}0.168 \\
{[0.031]^{* *}}\end{array}$ \\
\hline Town=Hartford & & -0.056 & & -0.127 & & -0.061 & & -0.045 & & -0.163 & & $\begin{array}{l}{[.031]} \\
-0.095\end{array}$ \\
\hline & & {$[0.006]^{* \star *}$} & & {$[0.004]^{* \star *}$} & & {$[0.021]^{\star \star \star}$} & & {$[0.029]$} & & {$\left[0.0311^{\star \star \star \star}\right.$} & & {$[0.035]^{\star \star *}$} \\
\hline Town=Waterbury & & -0.088 & & -0.136 & & -0.030 & & -0.096 & & -0.132 & & -0.022 \\
\hline & & {$\left[0.0066^{* * * *}\right.$} & & {$[0.003]^{* * *}$} & & {$[0.020]$} & & {$[0.027]^{* \star * *}$} & & {$\left[0.0300^{j * *}\right.$} & & {$[0.031]$} \\
\hline Town=Norwalk & & 0.026 & & -0.124 & & 0.006 & & -0.064 & & -0.129 & & 0.011 \\
\hline & & {$[0.011]^{\star *}$} & & {$[0.010]^{* * *}$} & & {$[0.019]$} & & {$[0.046]$} & & {$[0.080]$} & & {$[0.031]$} \\
\hline Constant & 0.170 & 0.185 & 0.132 & 0.132 & 0.626 & 0.154 & 0.165 & 0.281 & 0.1 & -0.019 & 0.650 & 0.277 \\
\hline & {$\left[0.001+t^{* * *}\right.$} & {$\left[0.0111{ }^{* * *}\right.$} & 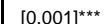 & {$[0.010]^{* * *}$} & {$\left[0.0055^{* * \star *}\right.$} & {$\left[0.0366^{* * *}\right.$} & {$\left[0.0100^{* * *}\right.$} & {$[0.058]^{\star \star \star}$} & {$[0.023]^{* * *}$} & {$[0.050]$} & {$[0.009]^{\star \star \star}$} & $10.0600^{* *+}$ \\
\hline Observations & 69488 & 69488 & 68859 & 68859 & 18586 & 185 & 3744 & 3744 & 572 & 572 & 7239 & 7239 \\
\hline R-squar & 0.000 & 0.046 & 000 & 0.0 & 0.000 & 0. & 0.002 & 0.052 & 0.002 & 0.137 & 0.000 & 0.178 \\
\hline F-Test $p$-value on three Secrecy Treatments & 0.001 & 0.001 & 0.621 & 0.30 & 0.700 & 0.657 & 0.003 & 0.003 & 0.319 & 0.122 & 0.180 & 0.187 \\
\hline F-Test $p$-value on two SOS Placebos & 0.858 & 0.845 & 0.564 & 0.590 & 0.087 & 0.070 & $\mathrm{n} / \mathrm{a}$ & $\mathrm{n} / \mathrm{a}$ & $\mathrm{n} / \mathrm{a}$ & $\mathrm{n} / \mathrm{a}$ & $\mathrm{n} / \mathrm{a}$ & $\mathrm{n} / \mathrm{a}$ \\
\hline Covariates included? & No & Yes & No & Yes & No & Yes & No & Yes & No & Yes & No & Yes \\
\hline
\end{tabular}

Note: Results from OLS Regressions with dependen
significant at $1 \%$. Full results matching to Table 5 . 